Article

\title{
Policy Innovation and Governance for Irrigation Sustainability in the Arid, Saline San Joaquin River Basin
}

\author{
Nigel W. T. Quinn \\ Climate and Environmental Sciences Division, Berkeley National Laboratory, Berkeley, CA 94720, USA; \\ nwquinn@lbl.gov; Tel.: +01-510-612-8802
}

Received: 11 April 2020; Accepted: 3 June 2020; Published: 10 June 2020

\begin{abstract}
This paper provides a chronology and overview of events and policy initiatives aimed at addressing irrigation sustainability issues in the San Joaquin River Basin (SJRB) of California. Although the SJRB was selected in this case study, many of the same resource management issues are being played out in arid, agricultural regions around the world. The first part of this paper provides an introduction to some of the early issues impacting the expansion of irrigated agriculture primarily on the west side of the San Joaquin Valley and the policy and capital investments that were used to address salinity impairments to the use of the San Joaquin River (SJR) as an irrigation water supply. Irrigated agriculture requires large quantities of water if it is to be sustained, as well as supply water of adequate quality for the crop being grown. The second part of the paper addresses these supply issues and a period of excessive groundwater pumping that resulted in widespread land subsidence. A joint federal and state policy response that resulted in the facilities to import Delta water provided a remedy that lasted almost 50 years until the Sustainable Groundwater Management Act of 2014 was passed in the legislature to address a recurrence of the same issue. The paper describes the current state of basin-scale simulation modeling that many areas, including California, are using to craft a future sustainable groundwater resource management policy. The third section of the paper deals with unique water quality issues that arose in connection with the selenium crisis at Kesterson Reservoir and the significant threats to irrigation sustainability on the west side of the San Joaquin Valley that followed. The eventual policy response to this crisis was incremental, spanning two decades of University of California-led research programs focused on finding permanent solutions to the salt and selenium contamination problems constraining irrigated agriculture, primarily on the west side. Arid-zone agricultural drainage-induced water quality problems are becoming more ubiquitous worldwide. One policy approach that found traction in California is an innovative variant on the traditional Total Maximum Daily Load (TMDL) approach to salinity regulation, which has features in common with a scheme in Australia's Hunter River Basin. The paper describes the real-time salinity management (RTSM) concept, which is geared to improving coordination of west side agricultural and wetland exports of salt load with east side tributary reservoir release flows to improve compliance with river salinity objectives. RTSM is a concept that requires access to continuous flow and electrical conductivity data from sensor networks located along the San Joaquin River and its major tributaries and a simulation model-based decision support designed to make salt load assimilative capacity forecasts. Web-based information dissemination and data sharing innovations are described with an emphasis on experience with stakeholder engagement and participation. The last decade has seen wide-scale, global deployment of similar technologies for enhancing irrigation agriculture productivity and protecting environmental resources.
\end{abstract}

Keywords: salinity; California agriculture; irrigation management; drainage; decision support 


\section{Introduction-Irrigation Development on the West Side of the San Joaquin Valley}

Irrigated agriculture development on the west side of the San Joaquin Valley (SJV) of California dates back to the middle nineteenth century, fueled by the California gold rush and the policy aims of the federal government to open up the western United States to economic development. Sustainable irrigated agriculture has two main requirements-an abundant supply of irrigation water delivered to the field at the right time and a water supply of adequate quality to maintain crop yields. The Irrigation District Law of 1887 (also known as the Wright Act) recognized that irrigated agriculture was beneficial to society and therefore deserving of public support [1]. This legislation emanated from prior basic and applied science directed at solutions to problems associated with increasing agricultural productivity and profitability. The Reclamation Act of 1902 provided public subsidies for irrigation projects for 17 states in the arid west following the basic premise of maximum resource utilization enhancing agricultural productivity. The federal Central Valley Project that was established in the 1930s transformed the economic, social, and political landscape of California's SJV. Patterns of agricultural land use and irrigation practices in the SJV have evolved since this time in response to changing resource conditions and technological innovation.

The advent of the deep-well turbine pump during the 1920s helped farmers extract good quality water for irrigation from deep aquifers, often with pump lifts of 2000 feet or more [1] (metric unit conversions may be found in Appendix A). By the 1930s, the negative effect of this large-scale groundwater utilization began to manifest itself in the form of land subsidence, particularly over the more actively pumped regions of the SJV such as the west side along Highway I-5, which historically received lower allocations of federal water supply. Figure 1 [2] shows the disaggregation of the Central Valley into major basins- the northern Sacramento Basin drainage by the Sacramento River; the San Joaquin (River) Basin (SJRB) drained by the San Joaquin River; and the closed Tulare Basin, which is usually further divided into the Tulare Lake and Kern sub-Basins. Irrigation water supply is conveyed largely by federally-owned facilities (Central Valley Project-CVP) in the Sacramento and San Joaquin River Basins and by the State Water project (SWP) in the Tulare Basin (Figure 1) [2]. The federal and state water agencies contract with local water districts (irrigation districts if they also purvey electrical power) for distribution to farmers and municipal customers. California is a state that recognizes both appropriative and riparian water rights. Appropriative water rights dictate the priority of water delivery to federal and state customers-which can create shortages for junior water right holders during dry and critically dry years when water deliveries can be cut back or even curtailed. Reliance on groundwater escalates during these water-year types-especially for those water users who have no other source of water supply, such as those west side farmers without riparian water rights to the SJR or Sierran tributary rivers (Figures 1 and 2) [2,3].

The alluvial fans on these margins of the Basin contain coarse-grained sediments with lower water-holding capacity requiring higher water applications. Inelastic, irrecoverable land subsidence in the Basin resulted from extraction that resulted in groundwater heads that exceeded pre-consolidation heads (the maximum decline in hydraulic head in the aquifer experienced historically) and that is associated with the initiation of new subsidence impacts. Aquifer consolidation occurs when the weight of the overlying strata exceeds the ability of the aquifer porous media and interstitial groundwater to support it. The largest deformation occurred in the soft sediment layers-predominantly clays and silts that form aquitards separating each aquifer layer. By the 1970s some west side land had subsided as much as 25 feet [1]. Moreover, the declines in pumping water levels ensuing from excessive groundwater extraction added significantly to the lift costs of pumped water. Over the past three decades, these limited objectives have come into conflict with emerging public awareness about the environment in general, particularly with the environmental impacts of irrigated agriculture. With or without further water development, greater conflict over water can be expected to occur, especially in years of shortage. No longer can demand for water be accommodated simply by the construction of a new reservoir or storage facility. 


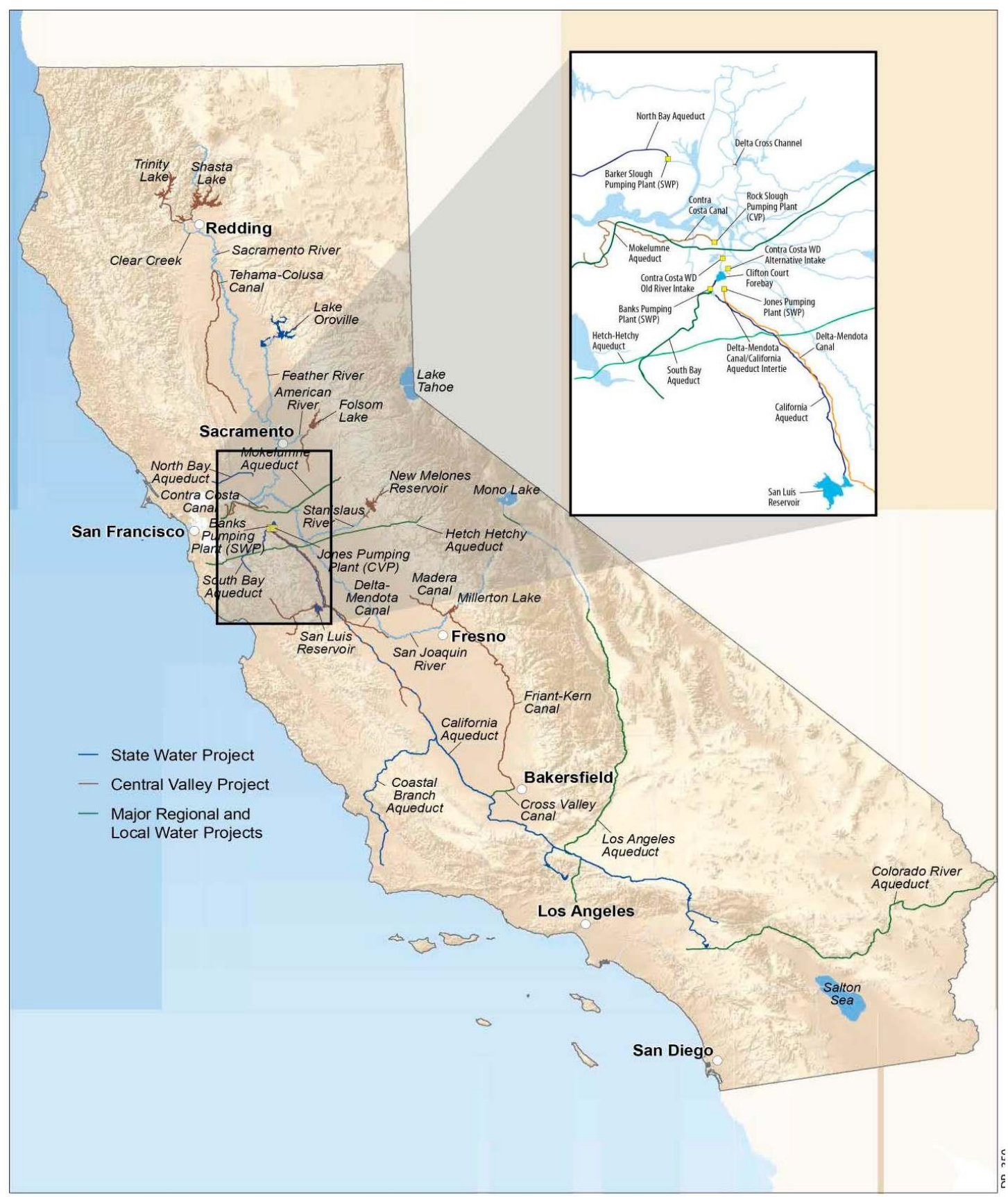

Figure 1. Map of California depicting the state, federal, and local water conveyance facilities and domain of service. Agriculture in the San Joaquin River Basin (SJRB) receives water through diversions from the SJR and the major east side tributaries-the Merced, Tuolumne, and Stanislaus Rivers and from the federal Delta Mendota Canal (DMC) and the shared (state-federal) California Aqueduct. Only the Sacramento and San Joaquin Basins have a drainage outlet to the Delta and San Francisco Bay-the Tulare Basin is a closed basin [2]. 


\section{Major Tributaries of the Sacramento-San Joaquin River Delta}

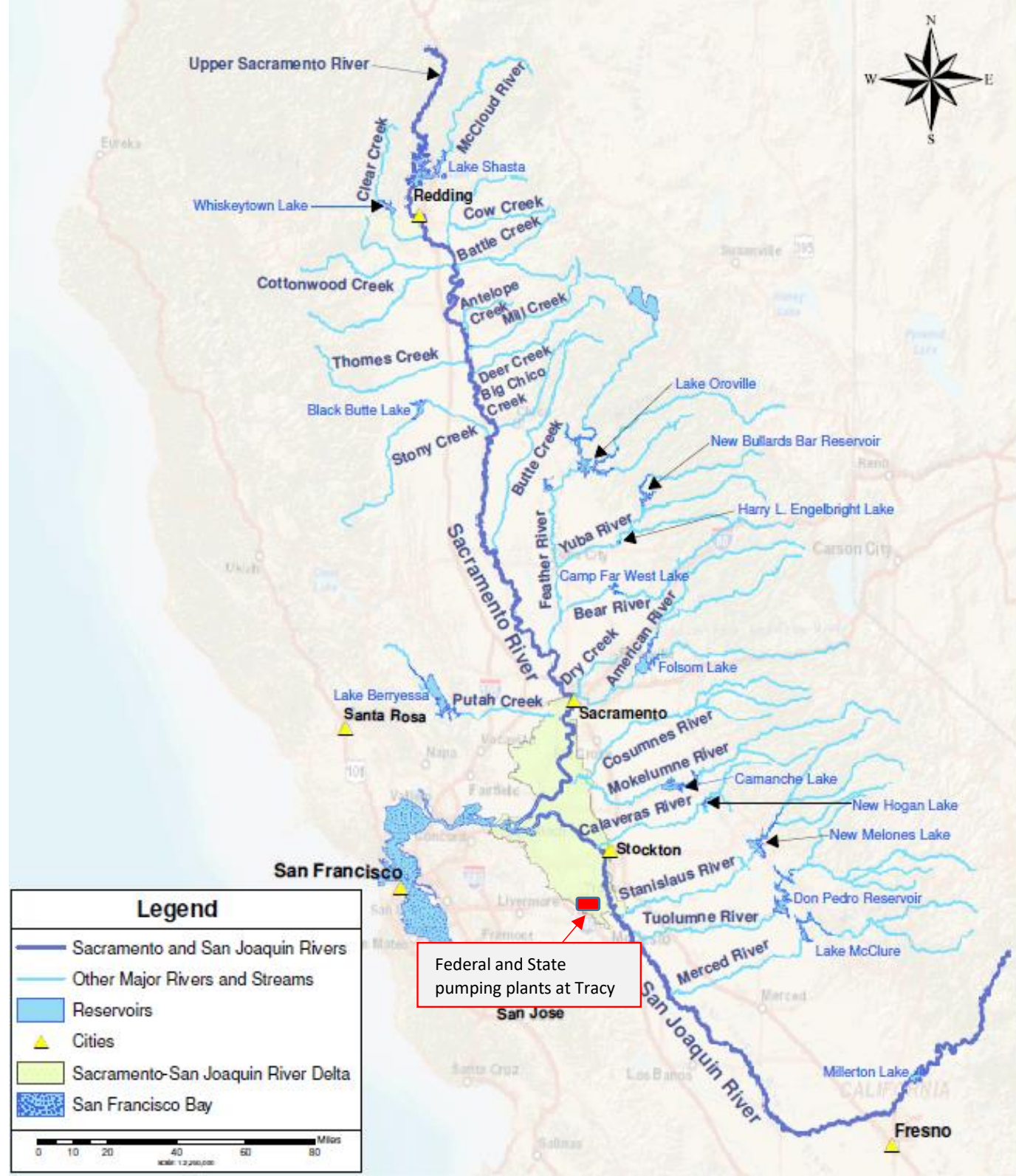

Figure 2. Detailed map of the San Joaquin River (SJR) and its major tributaries that provide drainage to the San Joaquin River Basin (SJRB). Irrigation water supply sources to agriculture in the San Joaquin Basin include direct diversions from the SJR and major tributaries, federal project water from the Central Valley Project (CVP) and groundwater. Reservoirs above the Valley floor on the east side tributaries are owned by the federal government and by local water districts. Major highways such as Interstate I-5 and Highway 99 are shown in light red running north and south in the SJRB [3].

Irrigation-induced salinization of land was observed and documented by Hilgard (1889) [4], who drew attention to the long-term consequences of irrigated agriculture in saline river basins in the United States and around the world. Salinity problems on the west side of the SJV of California are not unusual in river basins where the valley soils are developed in alluvial basins that once were covered by the ocean. What is unique about the west side of the San Joaquin Valley and the SJRB is 
the impact of selenium environmental toxicity on the drainage problem. The SJV occupies the southern two-thirds of California's Central Valley and the SJRB, the focus of this paper, is located in the northern portion of the SJV that drains to the Sacramento-San Joaquin Delta with an outlet to the Pacific Ocean. The characteristics unique to the combined water quality problems in this region have led to innovative policy responses and adaptive implementation solutions that continue to evolve.

California is blessed with highly regarded research institutions that have provided service to California agriculture for more than a century and commit significant state fund resources to develop technical and policy-oriented strategies to address this and other sustainable agricultural issues. This paper analyzes the role these institutions have played in addressing the water quality aspects of the problem to ensure irrigation sustainability.

\section{Water Supply Issues Impacting Irrigation Sustainability}

In the 1960s federal and state agency determination to arrest land subsidence and offset rising pumping costs led to a joint project to import surface water supply from the Sacramento-San Joaquin Delta to the south through the federal pumping plant of the Central Valley Project (CVP) located at Tracy. Water deliveries from the federal Delta-Mendota Canal (the major conveyance of the San Luis Unit of the CVP), which began in 1951, helped arrest subsidence and led to recovery of piezometric heads in the underlying aquifers to resemble pre-pumping levels. Although the piezometric heads in the confined aquifers recovered significantly, only about $10 \%$ of the total aquifer deformation was recovered due to the inelastic nature of the deformation. Distinguishing between elastic (recoverable) and inelastic (irrecoverable) deformation is important for understanding the long-term impacts on irrigated agriculture in the San Joaquin Valley and throughout the U.S. [5] However, regional groundwater models of the San Joaquin Valley have only relatively recently incorporated this feature [6].

This structural solution to the subsidence problem was largely successful at the time because much of the pumping occurred at great depth, below the Corcoran Clay confining layer, uniformly affecting the land surface and resulting in few of the infrastructure impacts associated with differential subsidence. Response at the agency level, although slow-some sites near Mendota had already declined by more than $35 \mathrm{ft}$ as evidenced by powerline poles-absolved stakeholders from having to bear the major financial costs of the intervention.

During the past decade, however, especially in the regions of the SJRB in close proximity to the San Joaquin River or along the alignment of the Delta-Mendota Canal (DMC) and the California Aqueduct, subsidence has once again been reported [5]. Data from a United States Bureau of Reclamation (USBR) monitoring site showed a subsidence rate of $0.6 \mathrm{ft} /$ year between December 2012 and December 2013 in the vicinity of Sack Dam on the SJR (Figure 3) [7]. The impacts of this more recent subsidence have been more dramatic-in some instances flooding out water control structures, causing cracks to the concrete canal lining, and reducing the capacity of irrigation canals. Unprecedented rates of well development occurred in response to the recent four-year drought that occurred between late 2011 and late 2015, which were the driest years since record keeping began in 1895. High temperatures worsened the impacts of the drought, with 2014 and 2015 witnessing the highest temperatures in the state's recorded history [1]. Actions by the state is this instance have been largely policy-oriented through the passage of the Sustainable Groundwater Management Act (SGMA) of 2014 [8] and have been complemented by actions at the local level, where alternate water supplies have been found to help offset the high volumes pumped by those stakeholders identified as the most likely contributors to the problem. Under SGMA, recently formed groundwater sustainability agencies (GSAs) are required to restore the groundwater basins in their jurisdiction to hydrologic balance by 2040 through implementation of policy guidelines and local actions enshrined in groundwater sustainability plans (GSPs). Rigorous adherence to these plans and actions achieved through consensus are meant to stabilize groundwater levels, decrease additional water quality degradation, and halt irreversible land subsidence and the damage to water conveyance infrastructure. The SGMA legislation recognizes seven co-equal policy objectives that together could achieve sustainable groundwater conditions by 
first identifying the major source and nature of the groundwater overdraft problems and then targeting management measures to ensure each basin operates within its long-term estimated sustainable yield [9]. These measures include.

- Reduction in the chronic lowering of groundwater levels that could lead to significant and unreasonable depletion of long-term groundwater supply if continued long-term;

- Reduction in significant and unreasonable losses of available groundwater storage;

- Interventions to eliminate significant and unreasonable impacts to the water quality of the groundwater resource through seawater intrusion;

- Other actions designed to prevent degraded groundwater quality;

- Targeted interventions to recognize and prevent future irreversible land subsidence;

- Actions to avoid depletions of interconnected surface waters that could have significant and unreasonable adverse impacts on existing and future surface water beneficial use (Cal. Water Code $\S 10721(w))$.

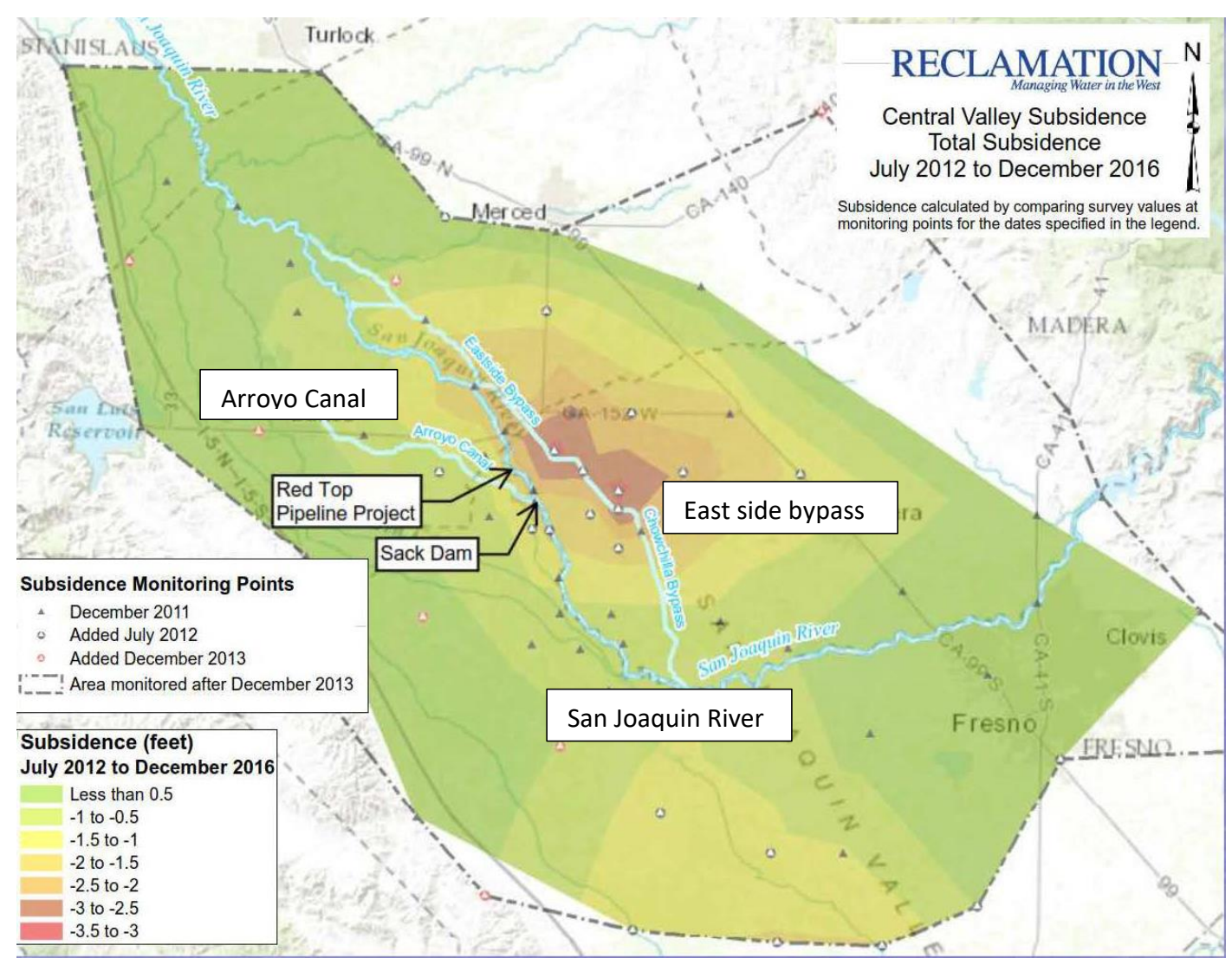

Figure 3. Total land subsidence measured between July 2012 and December 2016 in the SJRB. Subsidence jeopardizes the water supply deliveries for SJRB water districts that divert from the SJR along the Arroyo Canal with headworks near Sack Dam. The most significant subsidence of over $2.5 \mathrm{ft}$ occurred in the east side bypass that now conveys a portion of the SJR annual flow [10].

Implementation of SGMA by stakeholders in California will have a significant impact on agriculture, particularly in the southern SJV, where irrigators are more dependent on groundwater for the majority of their water supply. In some areas, it is likely that large amounts of agricultural land will need to be retired or enter fallow rotations-some predictions suggest up to 500,000 acres will need to be taken out of production over the next 10 to 20 years to achieve basin sustainability [11]. In the SJV GSAs can achieve groundwater sustainability in a number of ways, including 
(a) Recharging groundwater basins and temporary wetland areas on fields in areas where surplus water supply is available;

(b) Reducing water demand through crop substitution and increasing water use efficiency through infrastructure and irrigation technology investments;

(c) Converting agricultural landscapes to wildlife habitat that could improve potential recovery of many endangered species in the SJV [12];

(d) Fallowing, retiring, or converting land to municipal or industrial use such as renewable energy in wind or photovoltaic power. On land where agricultural productivity and potential wildlife habitat potential is low, renewable energy options may be cost-effective [13]. Reducing the land area devoted to agriculture may also improve air quality and eliminate groundwater nitrate levels that pose a public health threat associated with intensive agriculture [14].

Stakeholder response to SGMA legislation has been remarkably positive and proactive, given the decades of policy inaction on groundwater sustainability issues since the last major water agency intervention in the 1960s, previously described. This may be due in part to the widespread recognition of the severity of the problem, a reluctance to engage in years of unproductive litigation, and the fact that the state launched this policy initiative with a well-conceived conceptual plan that gives stakeholders substantial flexibility and scope for self-governance. The SGMA policy initiative may serve as an exemplar to other states and nations who are similarly placed to develop public-private partnerships for groundwater resource sustainability.

\section{Regional Groundwater Models to Guide SGMA Policy Planning and Future Irrigation Sustainability}

Implementation of SGMA will require reliable policy assessment and resource planning tools to support future water reallocation and water resource management decisions. SGMA policy requires the reporting of groundwater pumpage for the first time-requiring direct metering of groundwater extraction and allowing groundwater resource analysts to close hydrologic budgets, which hitherto were not easily validated. A significant case in point was the recent detailed comparison of two integrated regional surface-groundwater hydrologic models [15,16], the USGS Central Valley Hydrologic Model (CVHM) [6] and the state's Central Valley Simulation Model (C2VSIM) [17]. These agency models, which were developed as basin-scale planning tools covering the entire Central Valley (Figure 4), were those suggested by SGMA management as essential, publicly available tools for GSA analysis and GSP formulation purposes. Maples and others $[18,19]$ reported significant differences in annual estimates of both simulated agricultural groundwater pumping and aquifer storage when both were analyzed at regional and sub-regional scales (Figure 4).

Further analysis of the CVHM and C2VSIM model simulation results showed the greatest differences between the CVHM and C2VSIM models at the sub-regional scale-the scale most important for SGMA decision-making. This lack of agreement would also impact basin-scale salinity management, since many basin-scale salinity mass balance models are underpinned by regional scale hydrologic models such as CVHM and C2VSIM. Weaknesses in the capabilities of these major agency models will have implications for the utility of these models for salinity planning and management at the basin scale. Recent research by Maples $[18,19]$ and others identified potential sources of these model simulation discrepancies. The fact that input data sets were largely shared by the two models with minor differences in inputs such as land use designation and the number of crops considered suggests that the results of the comparison were most sensitive to model conceptual differences rather than data inputs, particularly at the sub-regional scale [19]. Additional questions have arisen related to the limitations of these model tools to guide sustainable groundwater pumping decisions, which suggests agency inertia in the adoption of newer and technically advanced techniques for the development of crop water budgets and crop evapotranspiration-the major water loss term in the hydrologic budgets. Techniques utilized by both models make use of estimates of potential crop evapotranspiration and crop coefficients, most of which come from handbooks and field data collected in the 1970s. Plant breeding and the development of more drought-tolerant cultivars have 
brought about changes in the water use requirements of these commonly grown agricultural crops, changing the quantity of water lost to evapotranspiration during the growing season. In this aspect both models may be subject to error and provide limited guidance to agricultural stakeholders. There were methodological differences over and above the crop coefficient that also contributed to model discrepancies. The CVHM model code calculates the E and T components of ET separately and does not independently simulate soil moisture, whereas the C2VSIM model code attempts to simulate root-zone soil moisture using a single algorithm to manage soil water depletion $[6,15]$.
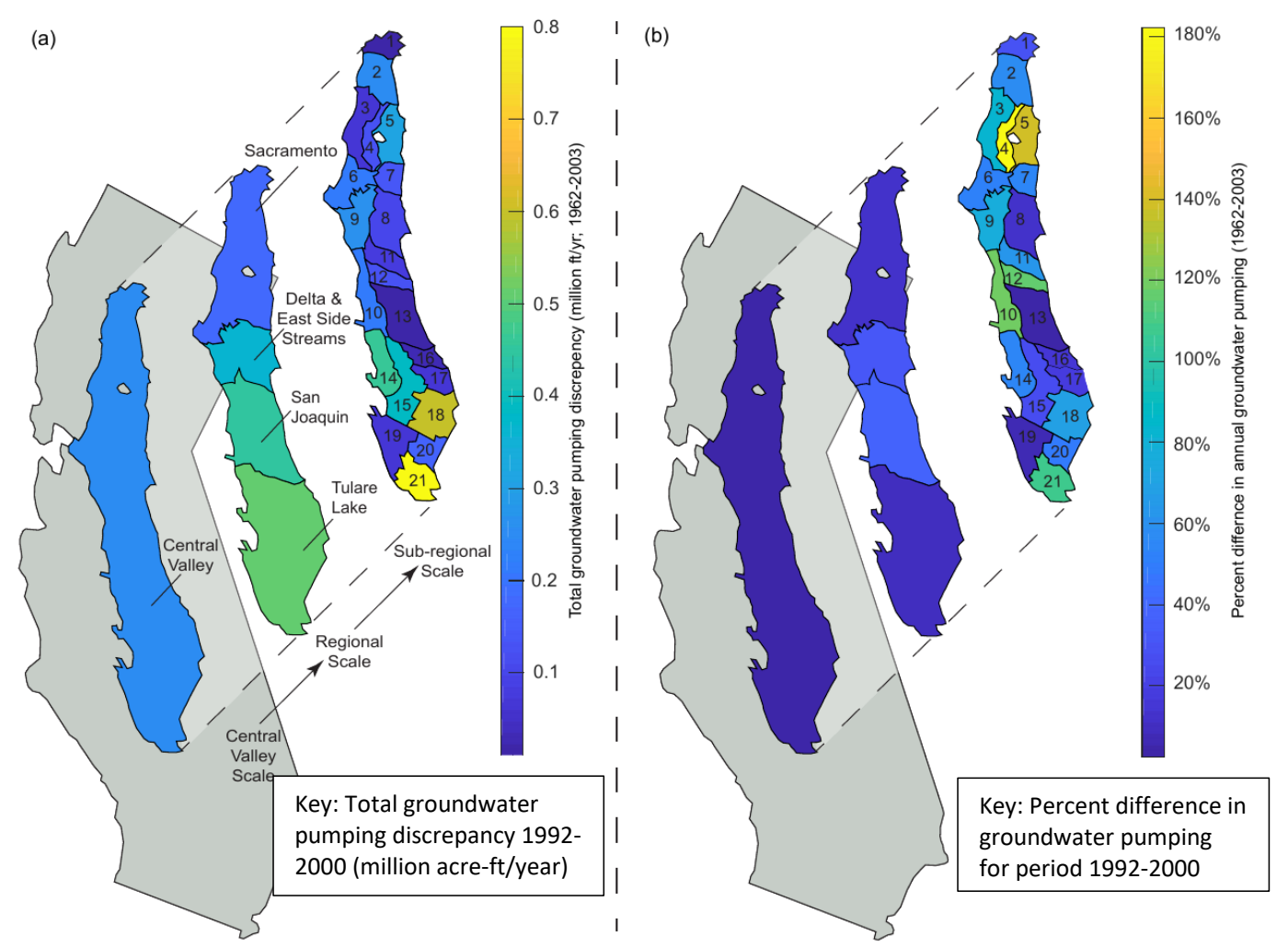

Figure 4. (a) Average annual groundwater pumping discrepancies and (b) percent differences in average annual groundwater pumping for the USGS Central Valley Hydrologic Model (CVHM) and Central Valley Simulation Model (C2VSIM) models at the sub-regional, regional, and supra-regional scale during 1962-2003 [13,15]. The SJRB is shown occupying the southern two-thirds of the Central Valley of California [17]. At the sub-regional scale, the average annual volumetric discrepancy between the CVHM and C2VSIM models' estimated groundwater pumping was 0.22 million acre-feet per year. All sub-regions showed a greater proportion of excess irrigation as deep percolation in CVHM, while C2VSIM showed a greater proportion of excess irrigation as runoff and return flow.

Whereas the CVHM model recognizes root-zone factors such as anoxia and deficit irrigation, these factors are ignored in C2VSIM. C2VSIM simulates irrigation hydrology separately for each crop within a sub-area that can be reduced in scale to a single model grid cell, whereas CVHM simulates this hydrology for the majority land use within each sub-area "farm." Farm size can also be defined as a single model cell. These and other factors, when extrapolated over a watershed or river basin, can lead to significant differences in the estimates of groundwater storage, aquifer pumping to meet irrigation demands, and estimates of land subsidence required under SGMA. One recent development that may help to reduce discrepancies in these groundwater resource planning and management tools might be the substitution of remote-sensing-based direct estimates of crop evapotranspiration to replace algorithmic-based estimates based on potential evapotranspiration and crop coefficients.

Reliable evapotranspiration (ET) estimation is a recognized limitation for water resources planning, irrigation water management, water regulation, and water quality estimation in both surface water 
and in groundwater and has been the subject of considerable research innovation in recent years [20,21]. Over the past decade, researchers have enhanced a number of remote sensing techniques and introduced new surveillance platforms to estimate ET. During October 2008 all remote sensing imagery collected by the LANDSAT 7 satellite became free to the public and by December 2009, all LANDSAT data archived by the USGS followed suit. The SEBAL (surface energy balance algorithm for land) was one of the early applications of remote sensing that used LANDSAT imagery to estimate daily evapotranspiration rates at the field scale $(30 \mathrm{~m})$ [18]. Remote-sensing-based evapotranspiration estimation techniques using "hot" and "cold" pixels have become more ubiquitous and have seen significant adoption by agencies and stakeholders alike with the SJV. "Hot" and "cold" pixels refer to the electromagnetic radiation from pixels representing dry land and irrigated land, respectively, that define the range of ET values [21]. The more popular and widely used techniques include METRIC (Mapping Evapotranspiration at high Resolution) and Google EARTHENGINE, which utilizes METRIC algorithms in a new formulation known as EEFlux (Earth Engine Evapotranspiration Flux) [21]. EEFlux is a comprehensive surface energy balance model that estimates net radiation (Rn), sensible heat flux to the air $(\mathrm{H})$, and conductive heat flux to the ground $(\mathrm{G})$, relative to measured reference evapotranspiration (ETr). ETr is the rate at which soil water is vaporized from vegetated surfaces, such as grass or alfalfa, based on the Standardized Reference Evapotranspiration Equation (ASCE-ET). Updating existing surface and groundwater hydrology models to take advantage of this new technology will likely resolve the more important technical issues that are constraining the use of these models for long-term resource sustainability planning and allow their eventual use for basin-scale salinity management.

\section{Water Quality Impediments to Irrigation Sustainability}

Irrigation sustainability in the SJV and SJRB, as previously stated, is a function of both future water supply and future projected water quality (primarily salinity) of irrigation applied water. Developing an understanding of SJV and SJRB hydrology is a prerequisite for understanding the dynamics of water quality in the Basin-however, water quality cannot be fully resolved without an appreciation for the physiography of the Basin that is responsible for the genesis and evolution of the Basin's soils. The SJV contains two hydrologic basins-the SJRB is an open basin that extends south of the Sacramento-San Joaquin Delta that drains into the SJR. The major tributaries to the SJR that provide drainage to the east side of the SJR are the Fresno, Merced, Tuolumne, and Stanislaus Rivers. The headwaters of these SJR tributaries receive water of high quality that provides dilution to poorer quality drainage from west side sources to the SJR. Dams on these tributaries to the SJR for flood control and irrigation water supply include Millerton Lake (on the SJR above Friant Dam), Lake Hensley (Fresno River), Lake McClure (Merced River), New Don Pedro Reservoir (Tuolumne River), and the New Melones Reservoir (Stanislaus River). The San Luis Reservoir, located above Highway I-5 on the west side of the SJRB, is an off-stream storage facility for the Central Valley Project (CVP) and State Water Project (SWP) and is hydraulically connected to the California Aqueduct and the DMC. The SJR provides riparian diversions for those stakeholders with water rights and who were not signatories to the Exchange Contract with the USBR that exchanged SJR water for diversions from the Sacramento-San Joaquin Delta.

Prior to development of the San Luis Unit of the CVP and the DMC, SJR water supply irrigated land on the west side of the SJV. Post-CVP construction, water released from Friant Dam (Millerton Lake) was diverted south to the Friant-Kern Canal to irrigate land in the Tulare Basin and the substitute water supply to the Exchange Contractors was supplied via the DMC, which, as its name implies, connects the Delta to the Canal's terminus in the town of Mendota. The Mendota Pool is another, much smaller CVP storage reservoir, located at the terminus of the DMC, which supplies the century-old agricultural canal distribution system that continues to be operated by the Exchange Contractors. This large-scale exchange of water rights had an environmental impact that was not fully recognized until later-ostensibly, the trade of a very high-quality, albeit less reliable, Sierran water supply for a 
more reliable, brackish water supply, pumped from the Delta. Salinity in the Delta pumped supply originates, in part, as agricultural returns from agriculture in the Sacramento and SJV municipal discharges and some blending of freshwater outflows to the Delta with tidal incursions from San Francisco Bay. The salinity of this new project water supply will be of importance in salinity management policy described later in this paper and the development of a salinity TMDL.

Although the primary source of salt to the SJR is in water supply imported from the Delta, it is important to recognize that soils on the west side of the Basin are sedimentary and alluvial in origin, having been formed in an uplifted seabed that became the Coastal Range that borders the west side of the Valley. The native salts in these soils mineralized and leached over time with the introduction of higher quality irrigation water, which led to rising saline water tables, especially in the Valley trough at the medial and distal ends of the alluvial fans where clay and silty clay soil textures predominate. For decades, the major constraint to crop productivity and irrigation sustainability was increased salinity due to soluble salt accumulation in the crop root zone and plant toxicity due to elevated concentrations of trace elements such as boron. As root-zone salinity increases, the crop must expend extra energy to overcome osmotic forces and extract nutrients and fresh water from the soil. High root-zone salinity correlates with high crop water stress [22-25]. This is remedied by flushing the crop root zone of excess salts through irrigation leaching, applied in excess of the crop's water requirement. This process is facilitated through installation of sub-surface tile drains, installed to remove the flushed salts and to control the proximity of the crop roots to the groundwater table $[22,24,26]$. Maintenance of a groundwater table five feet or more below the soil surface reduced root-zone evaporation and concentration of salts. An extinction depth of approximately seven feet is used as a typical threshold for west side SJV soils [27]. This extinction depth is defined as the limit of salt evaporative concentration and is a function of soil texture and capillarity.

Within the SJRB there are three major categories of land use: agricultural, wetlands, and urban/municipal. Administratively, agricultural lands within the SJV and SJRB are serviced by water (irrigation) districts that manage water conveyance, and drainage districts that often have the same footprint and are responsible for district drainage and investments in related drainage conveyance infrastructure. Federal, state, and private wetland entities operate like water districts although all rely on entities like the Grassland Water District to perform water-wheeling operations. The largest water district on the west side of the SJV is the Westlands Water District, most of which drains naturally to the closed Tulare Basin and which does not have a historic right to convey drainage water to the SJR. The San Luis Drain, which was originally designed to convey drainage to the Delta, has a terminus at Kesterson Reservoir [26]. While the Drain was in operation it provided drainage relief to 5300 acres of irrigated land in the northeast corner of Westlands Water District before drainage discharge ceased in 1986 by court order. Sub-surface tile drains were installed on approximately 135,000 acres of irrigated lands in the SJRB [26] to control seasonally elevated water tables and to dispose of accumulated salts in the crop root zone.

\subsection{The Kesterson Crisis and Policy Implications for Irrigation Sustainability}

In order to mitigate long-term salinity problems that were first recognized and described more than one hundred years ago in the SJV, the federal and state governments embarked on an ambitious joint policy and structural solution-a master drain designed to collect and convey mostly subsurface agricultural drainage from the west side of the SJV to the Delta. However, the reproductive failure of waterfowl and embryo deformities first observed at Kesterson Reservoir in 1983 and attributed to selenium poisoning from agricultural drainage became an environmental disaster for agency planners [28]. The selenium debacle cast a spotlight on the potential hazards associated with agricultural return flows and for a while distracted from the pervasive threat of long-term basin salination and the need for science-based salinity management strategies. It was also instrumental in creating a significant shift in public perception of the environmental impacts of agriculture that continues to this day. In hindsight, the early discovery of these problems may have averted a longer term, more serious 
disaster. The long-term chronic consequences of selenium contamination may have led to many more instances of nesting failure and wildfowl mortality. The Kesterson experience merely helped, albeit dramatically, to focus attention on the potential environmental consequences of intensive irrigation and subsurface drainage in an arid environment. Since the Kesterson crisis, other sites throughout the western U.S. have been identified where concentrations of selenium and other trace elements such as arsenic occur at potentially toxic levels [28].

The fallout from this event galvanized the U.S. Congress to launch two USD 50 million five-year research programs to gain knowledge of the fundamental science underpinning the selenium contamination issue and to fund a long-term selenium management and disposal solution for Kesterson Reservoir. The Kesterson disaster also highlighted the lack of preparedness within both state and federal agencies for dealing with this sort of event and the fundamental lack of scientific data and decision support tools needed to manage a credible crisis response. The state and federal agencies joined forces to create the San Joaquin Valley Drainage Program (SJVDP) with congressional appropriation and approached the University of California research community to address information and data gaps and to develop analytical modeling tools and procedures to provide long-term decision support for this and future environmental resource crises [26].

\subsection{Research Directed at Sustainable Solutions to Irrigation-Induced Water Quality Problems}

Agency analysts associated with the SJVDP formed the University of California Salinity Drainage Task Force, which became a primary vehicle to fund mission-relevant research activity at the major campuses of UC Davis, UC Riverside, UC Berkeley and the University of California, Los Angeles. These campus researchers formed partnerships and collaborations with agency scientists aside from those affiliated with the SJVDP, such as the U.S. Geological Survey, California Department of Fish and Game, U.S. Fish and Wildlife Service, and USBR, who helped to lend credibility to work being performed within the agencies and gave them access to superior laboratory research facilities within the universities. The studies funded ran the gamut of field-scale hydrologic and solute transport studies of selenium, boron, and other contaminants of concern to fish and invertebrate toxicity studies conducted in both field and laboratory. Annual results from these investigations were presented in an annual conference that continued into the late 1990s [26].

The hydrodynamicist and salinity model expert Orlob (1991) [29] analyzed historical data to determine the long-term state of balance between salt imported to and salt exported from the SJRB. Results of his study showed that since completion of the DMC, over 20 million tons of salt had been imported into the SJV through diversions. Water quality in the DMC is generally inferior to that in the California Aqueduct, owing to the proximity of the Tracy pumping plant (Figure 1) to the SJR confluence. Typical salinity of the DMC was between 400 and $500 \mathrm{mg} / \mathrm{I}$ total dissolved solids. The average salt accretion to the SJRB through the DMC was between 1.2 and 1.46, million metric tons per year [29]. Since the construction of the surface water reservoirs on the east side of the SJV and subsequent diversion of water along the Friant-Kern Canal, the average annual flow in the SJR (as measured at the Vernalis gaging station) declined by about 13 million acre-feet. Consequently, outflow of salt from the SJRB is now much smaller than that imported into the SJV by way of the DMC and the California Aqueduct. The remaining salt accumulates in the crop root zone or in the shallow groundwater aquifers beneath agricultural land on the west side. At the calculated rate of accretion Orlob calculated the net annual import of salt to be about 2.4 million tons by the year 2007 [29].

Other regional and sub-regional scale models have also served a useful purpose in the evolution of salt management policy in the SJRB-primarily to generate quantitative understanding of the fate and transport of salt from the point of diversion through to discharge to the SJR. Most models used for quantification of crop leaching requirements are based on mass-balances of water and salt using a theoretical one-dimensional column of soil extending from the soil surface to the groundwater table, which simulates water uptake in the crop root zone. These models utilize inputs of rainfall, applied irrigation water, and calculate crop evapotranspiration and the change in root-zone stored moisture as 
a function of time. Salt accumulation in the crop root zone accounts for salt imported with irrigation water, precipitation and dissolution of minerals, salts advected by root-zone deep percolation and any minor salt removal with the harvested crop. Although conceptually simple, accurate and reliable simulation of root-zone water balance and salt transport remains elusive at the field, watershed, and basin scales. Approximations such as the idealized model of Hoffman and van Genuchten [24] have used a linearly averaged salt concentration for the root zone. The most significant of these hydrology and water quality simulation tools was completed in 1987 as a collaboration between UC Davis and the State Water Resources Control Board. The San Joaquin River Input-Output (SJRIO) Model $[30,31]$ was the first comprehensive data-driven water quality simulation model of the SJR that became the basis for the Watershed Analysis Risk Management Framework (WARMF) forecasting model underpinning the Real-time Salinity Management program presented in the last section of this paper.

Although not part of the University of California research consortium, members of the Irrigation Technology Research Center (ITRC) at California Polytechnic University (CalPoly) played a key role by providing a technical liaison between individual growers, water districts, and agency planners-providing realistic field and farm data for use in agency models [32,33]. CalPoly agricultural engineers recognized the importance to growers of correctly estimating the crop leaching requirement, the importance of developing a shared understanding of how irrigation efficiency is estimated and the fact that field and farm assessments of irrigation are closely tied to grower behavior [33]. Irrigation efficiency has been defined differently in the literature for both practical and policy purposes. A common definition of crop irrigation efficiency is the ratio of the applied irrigation water to the proportion of that water beneficially used by the same crop. Beneficial use refers to the annual crop water requirement. Irrigation consultants occasionally adopt a broader definition of crop beneficial use that includes a minimum leaching requirement and allowance for frost protection and other routine cropping practices. These additional factors usually produce higher estimates of irrigation efficiency and can result in estimated irrigation efficiencies of greater than $100 \%$ in instances where upward capillary flow from shallow groundwater can satisfy a portion of crop ET. In these circumstances the event-based irrigation efficiency can increase over the irrigation season with crop root development and the increased ability to access capillary water from the shallow groundwater table. Burt et al. [33] stress that the selection of an appropriate irrigation efficiency in salinity management models at all scales should be done judiciously and be transparent to irrigation consultants and agency planners alike so as to maintain confidence in the use of these models. Different ontologies for computation of important factors such as irrigation efficiency can lead to differences in model outputs, as described earlier in the case of the CVHM and C2VSIM models.

Researchers at CalPoly's ITRC also provided practical advice [32,33] that provided guidance for the interpretation of agency planning simulation models. An example is the maxim that maximizing water use efficiency is not always in the best interests of the grower in fields and farms where soil texture is heterogeneous and high irrigation application distribution uniformity performance for furrow and basin irrigation systems is hard to achieve. ITRC guidelines suggested a practical distribution uniformity goal of $80 \%$ for most furrow irrigation systems. The ITRC researchers also suggested that high irrigation water use efficiency was not likely for those irrigation systems with poor distribution uniformity if sufficient water is to be applied that satisfies crop ET requirements. In cases where there is cost associated with drainage disposal measured either according to volume or salt load, it can be more cost-effective to maximize investments that improve water use efficiency and help reduce drainage discharge.

Irrigation and drainage unit costs were incorporated by the SJVDP in the development of the Westside Agricultural Drainage Economics (WADE) model [34,35]—a seasonal agricultural production and hydrosalinity model designed to make long-term projections in irrigation and drainage technology in response to drainage policy options. WADE model simulations showed that increased costs of drainage disposal, applied to the WADE model as cost constraints of the agricultural production 
function, led to investments in water-conserving irrigation technologies such as shortened rows, sprinkler or drip irrigation, which, in turn, reduced irrigation applied water [35]. In circumstances where model sub-areas received less than an optimal water supply, the model reduced ET, which led to a reduction in crop yield. During severe drought when water deliveries to irrigators can be reduced by as much as $75 \%$, prompting irrigators to choose between fallowing large tracts of farmland and/or deficit-irrigating crops, the WADE model allowed both to be simulated while also factoring in the costs associated with well pumpage [35]. The WADE model realized the potential yield reduction associated with elevated water salinity in well pumpage during the subsequent irrigation season and elevated salinity in the crop root zone [35].

The WADE hydrosalinity model simulated downward displacement of salts from root zone to shallow aquifer and between the shallow semi-confined aquifer (set at an elevation of $50 \mathrm{ft}$ below the soil surface) and the deep semi-confined aquifer that was bounded by the top of the Corcoran Clay. The WADE model also recognized a sub-Corcoran aquifer that was the major zone of well pumpage and where salinity levels were assumed to be below $1500 \mathrm{ppm}$ [35]. Aquifer characteristic data such as layer depths, hydraulic conductivities, storage coefficients, and aquifer anisotropy values were derived from the U.S. Geological Survey regional simulation model developed by Belitz $[35,36]$. Cross-Corcoran fluxes were similarly used directly by the model. Reuse of shallow groundwater is a process also captured by the WADE model that can have a significant impact on estimated system and crop irrigation efficiency as well as salinity concentration in the crop root zone because of salt evaporative concentration. When subsurface drainage is available, a portion of the saline percolating water may be intercepted by the tile drains and subsequently discharged to sumps or surface drainage ditches. The WADE model allowed specification of this intercepted portion removed from the shallow aquifer layer. The WADE model used a simplified link-node algorithm, calibrated using MODFLOW ZONEBUDGET output from the USGS regional model [36] to simulate lateral flow between adjacent sub-areas. The WADE model did not capture scenarios where complex lateral groundwater flow patterns exist and where groundwater salinity is impacted by groundwater gradients. The WADE model adopted the USGS conceptual model [36] of a vertically dominant aquifer where groundwater flow is predominantly in the vertical direction and horizontal flow less significant in response to shallow groundwater gradients. In this manner, shallow groundwater salinity can, through the process of evapo-concentration, achieve a concentration of 20 to 30 times the applied water salinity for undrained soils and around five times the applied water salinity for drained soils.

\subsection{Surface and Groundwater Strategies for Sustainable Irrigation}

Groundwater is increasingly recognized as valuable natural resource, as evident from the SGMA policy and legislation described earlier, and the strong connection between surface and groundwater ensures not only a sustainable water supply but also that groundwater aquifers provide water of sufficient quality for sustainable irrigation. Deep percolation of irrigation applied water displaces better quality groundwater; the rate at which this displacement occurs is a function of the rate of groundwater extraction from the deep semi-confined and lower confined aquifers, which, in turn, can affect the vertical hydraulic gradient driving the flow of groundwater between aquifers. Reversing long-term irrigation-induced salinization of these groundwater aquifers requires quantifying current day practices such as over-irrigation and groundwater mining coupled with improving information on how irrigation leaching requirements can be optimized through more effective irrigation scheduling and the selection of appropriate irrigation technologies best tailored to match crop ET requirements. One management strategy [37] sought to maintain the salinity concentration in the root zone at a level tolerated by the plants without leading to yield declines. The researchers described how dynamic programming methods can help to redesign irrigation schedules to better manipulate salts in the soil profile. The selection of irrigation technology (e.g., furrow, drip, etc.) as well as the intensity of irrigation water management can affect the ability of irrigators to control the distribution of salt in the soil profile. Others [38] concurred that adoption of new technologies alone would have a limited effect on improving 
irrigation water use efficiency and controlling soil salinity—-these need to be complemented by active management using decision support tools and a combination of water application and drainage control strategies to achieve irrigation sustainability goals. The U.S. Department of Agriculture Agricultural Research Service (USDA-ARS) [39] described a number of on-farm techniques sanctioned by the USDA to improve irrigation water use efficiency and control salinity. These techniques include: improved irrigation and drainage technologies; a reduction in pre-plant irrigation applications; better management of deficit irrigation for certain crops as they near maturity; partial reuse of drain water; and the use of on-farm indicators and decision support tools to dynamically guide irrigation water applications. Irrigation technologies covered include furrow, corrugation, basin and border irrigation, as well as micro-irrigation technologies comprising surface and subsurface drip irrigation and sub-irrigation [40]. Sprinkler irrigation systems also can be acquired in a number of forms including permanent, moved, side roll, and center pivot systems that can be optimally matched to various crops, cropping practices, soil conditions, and active management capabilities.

\subsection{Economic Factors Impacting Sustainable Irrigation Policy}

While process-based simulation models can relate crop yield and drainage salt load to a variety of water application and drainage strategies, certain activities aimed at improving crop yield may conflict with SGMA goals of sustainable protection of groundwater quality in the shallow groundwater aquifer on the west side of the SJV. These conflicting objectives may be similarly constrained by economic considerations of cost and benefit. To identify the optimal irrigation strategies, linear and dynamic programming methods [41] were studied that consider crop water requirements, soil salinity, and the costs of production both at the individual farm and water district levels. This selection process can be accomplished with dynamic optimization at the farm level over a sequence of years under various permutations of crop rotation, soil salinity management practices, and investments in irrigation and drainage technologies, as demonstrated by Knapp [42-44]. Dinar et al. [45] also used dynamic programming models to develop a policy analysis framework for irrigated agriculture sustainability in arid environments such as the west side of the SJV. Dinar's model used data-derived, empirical input functions for factors such as crop yield, salinity, and drainage discharge and used a production model objective function with both cost and revenue terms [45]. The economic model of irrigation sustainability suggested that direct drainage control policies exacting penalties for saline drainage discharge were slightly more cost-effective than indirect control policies. The research concluded that dynamic models may be overly complex for this class of problem given the fact that these agro-economic systems often converge to a steady state, eliminating the dynamic model requirement that time be considered an independent variable. In practical terms, dynamic optimization is computationally intensive and requires significant computer resources to run the model quickly, more so when the interacting physical, chemical, and anthropogenic system inputs are complex. Under these circumstances, dynamic optimization may be more useful as a tool for screening various policy or management options, followed by the evaluation of specific management options using more detailed and comprehensive process-oriented simulation models [41]. Social behavior modeling can also offer insight into adaptive behavior and technology adoption as growers and water districts evolve towards greater sustainable utilization of natural resources for sustainable irrigation and drainage salinity management [46-48].

\subsection{Regional Policy Planning and Assessment Models for Irrigation Sustainability}

Policy planning and assessment models are often integrated with the process-oriented models described above and typically focus on large regions at the scale of the SJV or SJRB. These models often relate economic objectives to resource constraints and responses. Physical and chemical processes, defined at the field and farm scale, become less and less meaningful as the spatial scale expands to the regional scale. Hence regional scale planning and assessment models utilize fewer parameters and typically combine model parameters into a smaller number of lumped parameters in order 
to generalize responses to the most sensitive hydrologic, agronomic, and geochemical processes and interrelationships. When available, these regional scale models can use empirical relationships derived from higher resolution and more detailed models, given that regional scale models are more difficult to calibrate and validate. Models used in agency planning studies emphasize model output comparisons between potential future scenarios and no-action and base conditions rather than promise accurate and reliable model predictions. A successor to the previously described Westside Agricultural Drainage Economics (WADE) Model [35], the Agricultural Production Salinity Irrigation Drainage Economics (APSIDE) model [49] is a good example of this class of policy model. Unlike the WADE model, the APSIDE model was reworked to simulate the same agricultural production and income projections in response to irrigation water quality and drainage policy constraints and a monthly timestep to allow linkage to a climate-driven water resource allocation model (CALSIM-II) and an SJR water quality model (WARMF). Output from the model suggested optimal investments in irrigation and drainage technology over the 50-year planning horizon in response to monthly drainage salt load constraints and irrigation water supply salinity that was expected to degrade with climate change in the SJRB. The APSIDE model production function used the same empirical algorithm calibration technique for the agricultural production function as was used in the WADE model, which set annual cropping practices and made changes to irrigation and drainage investments at the beginning of the irrigation season. It used an error minimization algorithm in lieu of the production function for each month of the simulation to resolve hydrology and salinity mass balances [49]. Major APSIDE decision variables, some of which were supplied by linkages to water allocation models such as CALSIM to address climate change impacts, included: water supply, water supply water quality, crop selection, irrigation and drainage improvement costs, groundwater pumping, drainage recycling, water transfers between regions, and land use changes.

\section{Evolution of Environmental Policy Mandates Impacting Irrigated Agriculture}

The Kesterson selenium crisis and the stigma newly inflicted on irrigated agriculture in the SJV that suggested that agriculture posed a threat to SJRB environmental quality, weakened alliances that had previously formed with urban and municipal interests and with the environmental lobby. Agricultural interests had aligned with cities to assist in drought mitigation by voluntarily fallowing land during dry and critically dry years and providing additional water supply to cities. Likewise, rice farmers embraced winter flooding of rice fields, eliminating annual rice burning and the smoke and particulate pollution that followed, also providing essential overwintering habitat to migratory waterfowl on the Pacific Flyway. These alliances became fractured and a weakened agricultural lobby led to an unprecedented reevaluation of federal water contracts within the CVP, resulting in the so-called "Miller Bill" (CVP Improvement Act PL 102-575 Title 34). The Environmental Impact Statement (EIS) requirement for contract renewal for each CVP contract reduced the total allocation of federal developed water to agriculture by 800,000 acre-feet and redesignated this water allocation for fish and wildlife purposes. The Miller Bill redressed the loss of wetland acreage that had occurred over the past century, diminishing it from four million acres to a little over one million acres by the early 1920 s and to about $10 \%$ of the original wetland area of 1850 [1]. Agriculture on the west side of the SJV found itself constrained by the seemingly opposing objectives of economics on the one hand and the less tangible objectives of quality of life, stemming from prosperity. The net result was also a turning away from voluntary accommodation of irrigated agriculture, more questioning of the ability of agriculture to conduct business in a sustainable fashion, especially in the western SJV and the SJRB, and a preference for future legislative and environmental policy solutions after the success of the Miller Bill.

A common tool for water quality regulation used throughout the conterminous U.S. is the EPA-supported Total Maximum Daily Load (TMDL). The TMDL is a regulatory tool for allocating responsibility for pollution in impaired waterbodies by estimating the assimilative capacity of the waterbody for the pollutant, determining the mass loading from point and non-point sources 
contributing to this impairment, and developing downstream water quality objectives in the waterbody that are rarely exceeded. Compliance is achieved in the TMDL methodology by choosing a conservative lowest $10 \%$ hydrologic condition and an adequate margin of safety. For salt management in the western U.S. this methodology can be excessively restrictive and costly for agricultural stakeholders [50].

The ability to craft a credible science-based TMDL is predicated on the ability to develop a data-driven modeling approach, which is especially important in the SJRB where powerful political forces are aligned with agricultural, urban municipal, and environmental interests that often have competing development and resource sustainability agendas. Although, as noted in the previous sections on water supply and water quality in this paper, the groundwater resource sustainability problem and the Kesterson agricultural drainage-induced water quality crisis have together ensured a deep well of discrete and agency-sponsored routinely collected data to launch a defensible model-based analytical approach. Although no modeling approach is without its flaws, since models are typically conceived and funded for a specific purpose and are not always supported beyond the initial problem mandate. Under SGMA renewed concern about aquifer subsidence has allowed agencies to rehabilitate aquifer extensometer monitoring sites that had not been actively maintained since the 1960s [7]. New remote sensing for estimating land surface deformation, such as InSAR, have allowed the collection of accurate regional subsidence data at a fraction of the cost of maintaining an extensometer monitoring station. Similarly, many of the core flow gaging and water quality monitoring stations that were installed in the aftermath of the Kesterson crisis have been maintained through a combination of state and federal water agency and local agency support and most recently by the San Joaquin River Restoration Program. These stations have provided analysts with a sufficient data record to allow calibration and validation of models such as the San Joaquin WARMF (Watershed Analysis Risk Management Framework), a data-driven flow routing and comprehensive water quality simulation model [51] that has supplanted the SJRIO model, previously described, which provided the basis for the SJR salinity TMDL.

\subsection{Salinity Load Regulation Methodology for the SJRB}

The Central Valley Regional Water Quality Control Board's (CVWB) Salt and Boron Total Maximum Daily Load (TMDL) for the SJR [52,53] was approved on 28 July 2006. In response to the Salinity and Boron TMDL, the USBR adopted a salinity control plan entitled "Actions to Address the Salinity and Boron TMDL Issues for the Lower SJR" and entered into a Management Agency Agreement (MAA) with the CVWB on 22 December 2009. The MAA describes the actions the USBR will take to meet Salinity and Boron TMDL obligations, in particular, maintaining compliance with salinity objectives of $700 \mu \mathrm{S} / \mathrm{cm}$ during the irrigation season (1 April-31 August) and $1000 \mu \mathrm{S} / \mathrm{cm}$ during the non-irrigation season (1 September-31 March) measured as a 30-day running average electrical conductivity (EC) at the Vernalis compliance monitoring station. The Action Plan also describes procedures to manage and mitigate adverse impacts of salt and boron imported into the SJRB via the USBR's DMC as included in the CVWB's most recently amended Water Quality Control Plan for the Sacramento River and the SJRB [53]. The USBR routinely provides dilution flows from the New Melones Reservoir on the Stanislaus River to meet the Vernalis 30-day running average salinity objectives when there is insufficient salt load assimilative capacity in the SJR.

\subsection{Model-Based TMDL Salt Load Allocation Methodology}

The CVWB salinity TMDL model methodology, supported by archival and current discrete and continuous flow and EC monitoring data, followed a protocol that the CVWB believed would be perceived as equitable and fair. Regulators divided the SJRB into seven watershed-based sub-areas that contribute flow and salt loads to the SJR. The Grassland sub-area of the west side regularly contributes between $50 \%$ and $65 \%$ of the total salt load in the SJR, followed by the northwest side sub-area (Figure 5). Growers in both sub-areas obtain irrigation water supply from the DMC, the SJR, and local groundwater. Irrigation drainage recycling in both sub-areas contributes to the available water supply. The TMDL 
approach is designed to assign to each contributing sub-area a salt load allocation based on the sub-area average annual contribution to the salt load scaled back and weighted, using techniques to account for water-year types with low monthly SJR salt load assimilative capacity, measurement uncertainty, and an inherent lack of central coordination of drainage scheduling. This lack of coordination between west side sub-areas contributing the highest salt loads and east side sub-areas (the tributary watersheds and the East Valley Floor sub-area) that provide SJR dilution through reservoir releases along the three major Sierran tributaries prevents full use of the SJR salt load assimilative capacity. The TMDL is unusual in that it recognized the federal water agency and purveyor of water supply as a primary stakeholder, given that this supply introduced salt loads to the SJR elevated above historic background levels for normal east side tributary inflow to the SJR. The Sacramento-San Joaquin Delta is the source of the USBR water supply delivered via the DMC to both the Grassland and Northwest sub-areas (Figure 5). The salinity of this supply water can degrade along the DMC because of inflow of storm drainage and runoff, subsurface drainage from interceptor drains, and pumped groundwater from wells along the canal alignment that help to increase the total volume of water supply delivered to federal Central Valley project (CVP) contractors.

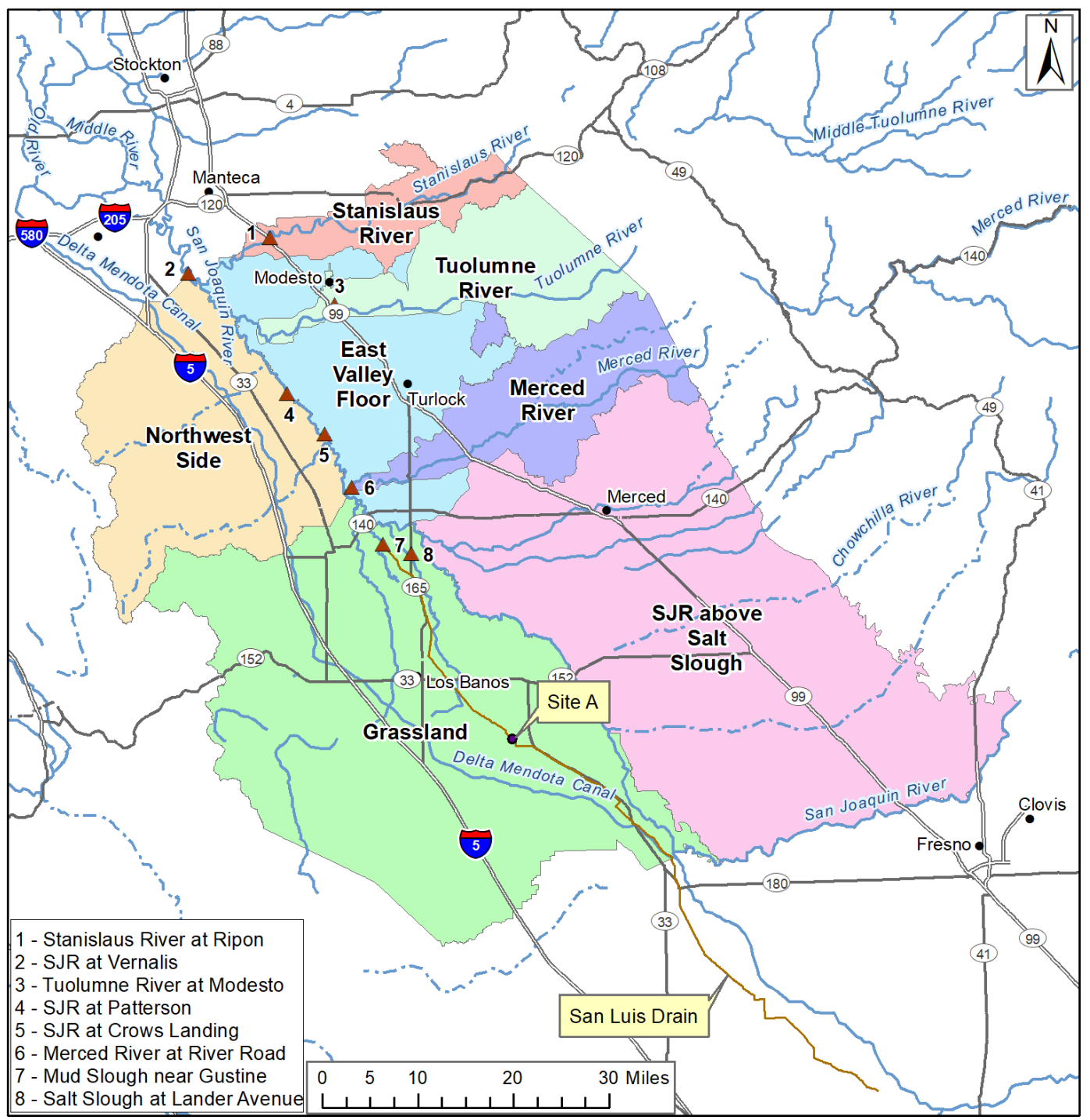

Figure 5. SJR Basin showing contributing sub-areas as defined in the 2002 TMDL [50]. This figure shows the alignment of the Delta-Mendota Canal (DMC) and the San Luis Drain that terminates at Kesterson Reservoir. Major SJR and west side and east side tributary monitoring stations are also shown. 


\subsection{West Side Salinity Sources}

The CVWB periodically updates their SJRB Water Quality Control Plan, which allocates a salt load to the USBR for water supply delivered to CVP contractors on the west side of the SJRB. The load allocation (LA) for these DMC deliveries to the Grassland and Northwest side sub-areas was calculated as follows:

$$
\mathrm{LA}_{\mathrm{DMC}}=\mathrm{Q}_{\mathrm{DMC}} * 52 \mathrm{mg} / \mathrm{L} * 0.0013599,
$$

where

$\mathrm{LA}_{\mathrm{DMC}}=$ Load Allocation of salt for DMC water deliveries (tons)

$\mathrm{QDMC}_{\mathrm{DMC}}=$ monthly volume of water delivered to Grassland and Northwest side sub-areas (acre-feet)

$52 \mathrm{mg} / \mathrm{l}=$ "background" TDS of SJR water at Friant Dam (SJRB Basin Plan)

$0.0013599=$ TDS unit conversion factor $(\mathrm{mg} / \mathrm{L}$ to tons/acre-feet)

Salt loading above this load allocation was considered an "excess" salt load, which must be offset by watershed sources that increase SJR salt load assimilative capacity or that reduce non-point source salt loading. The USBR agreed upon a suite of actions, described in the stakeholder-endorsed SJRB Action Plan, that was designed to offset this excess salt load. Excess salt loads (EL $L_{D M C}$ ) were calculated as follows:

$$
\mathrm{EL}_{\mathrm{DMC}}=\mathrm{Q}_{\mathrm{DMC}} *\left(\mathrm{C}_{\mathrm{DMC}}-52 \mathrm{mg} / \mathrm{L}\right) * 0.0013599,
$$

where

$\mathrm{EL}_{\mathrm{DMC}}=$ excess salt load above the Load Allocation ( $\left.\mathrm{LA}_{\mathrm{DMC}}\right)$, in tons

$\mathrm{C}_{\mathrm{DMC}}=$ monthly average (arithmetic mean) of salinity of the water delivered to Grassland and Northwest sub-areas, in $\mathrm{mg} / \mathrm{L}$

QDMC was calculated for each reach of the DMC to the point of delivery and paired with the associated monthly average TDS (from measured EC) for the same reach to produce the equation

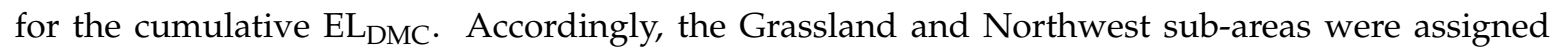
independent salt load allocations described as water supply credits that are a function of the total volume of water delivered to each sub-area. Water deliveries were apportioned by sub-area where the DMC supplied water across the sub-area boundary. The calculated Consumptive Use Allowance is the product of the actual monthly flow volume and a trigger salinity value of $192 \mathrm{mg} / \mathrm{L}$ TDS, which was assumed equivalent to the mean salinity of drainage return flows after accounting for seasonal crop evapotranspiration for an irrigation water supply with a salinity of $52 \mathrm{mg} / \mathrm{L}$.

\subsection{Quantification of East Side Assimilative Capacity Generating Flows}

The U.S. Congress authorized the construction and operation of New Melones Reservoir on the Stanislaus River as a multi-purpose facility, which includes water quality as a qualified use. Non-consumptive water releases from this reservoir are of high quality and provide significant dilution flow for salinity in the SJR. Other releases of stored water from New Melones are made for instream fishery benefits and to maintain the dissolved oxygen level in the Stanislaus River above the confluence with the SJR. Any time these routine releases are insufficient to decrease SJR salinity below the 30-day running average salinity objective at Vernalis (Figure 5; Site 2) additional water quality releases are scheduled by the USBR to maintain salinity compliance and offset excess salinity loads imported through the DMC.

The current CVWB Basin Water Quality Control Plan specifies that entities providing dilution flows obtain an allocation equal to the salt load assimilative capacity provided by this flow (Figure 6). This allocation is only applied if the dilution flow being quantified provides measurable dilution in the SJR to the Vernalis compliance monitoring station and creates assimilative capacity without interfering with the Stanislaus River sub-area's salt load allocation. 
Subarea Allocation

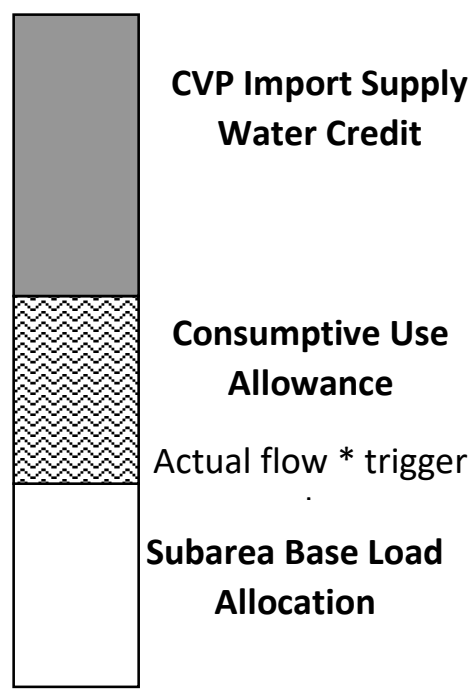

Subarea Load

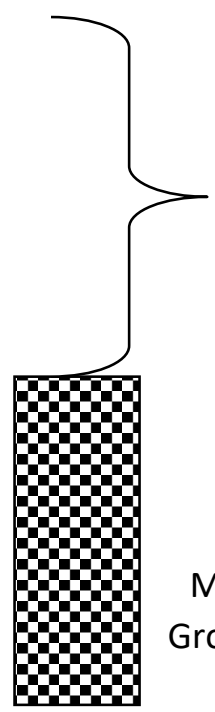

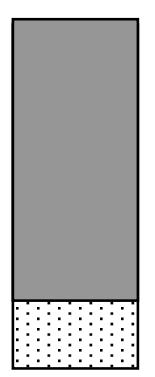

Portion that offsets CVP Import Load

Assimilative Capacity from Subarea

Allocation - Measured Load

\section{Measured Load}

Measured flow * EC-

Groundwater Accretions

Figure 6. Monthly assimilative capacity calculation for the Grassland sub-area [52]. In each case the monthly measured load (adjusted for the estimated salt load from groundwater accretions) should be added to the CVP salt load offset (provided by USBR dilution flow from New Melones Reservoir) and compared to the monthly sub-area allocation. The difference between these totals is the monthly sub-area salt load allocation or assimilative capacity unused. If this number is negative the salt load is in excess of the salt load allocation and the sub-area is out of compliance and could be subject to a fine.

To calculate the assimilative capacity (Figure 7) created by the USBR's operations on the Stanislaus River both the actual salt load and the salt allocation of the River were calculated. The monthly salt load was subtracted from the monthly salt load allocation to determine available salt load assimilative capacity [32]. A site-specific ratio of 0.69 was used for all east side tributaries to convert EC to TDS. The actual salt loading was calculated as follows:

$$
\mathrm{L}_{\text {actual }}=\mathrm{Q}_{\text {actual }} * \mathrm{C}_{\text {actual }} * 0.69 * 0.0013599 \text {, }
$$

where

$\mathrm{L}_{\text {actual }}=$ actual tributary salt loading (tons/month)

$\mathrm{Q}_{\mathrm{actual}}=$ actual flow volume (acre-feet $/$ month)

$\mathrm{C}_{\text {actual }}=$ monthly mean $\mathrm{EC}(\mu \mathrm{S} / \mathrm{cm})$

$0.69=$ TDS:EC ratio specific to Stanislaus River

$0.0013599=$ TDS unit conversion factor $(\mathrm{mg} / \mathrm{L}$ to tons/acre-feet)

The salt load allocation to the Stanislaus River sub-area was calculated as the sum of its Load Allocation (LA) and the Consumptive Use Allowance, as previously defined.

Likewise, salt load assimilative capacity allocations for the Merced River and Tuolumne River sub-areas were calculated as the sum of the Base Load and the Consumptive Use Allowance allocations. Flow data for the Tuolumne River were obtained from the USGS stream gaging station at Modesto (11290000) and for the Merced River at the USGS stream gaging station near Stevinson (11272500).

Fish and wildlife protection, restoration, and enhancement became important USBR project purposes with the passage of the Central Valley Project Improvement Act (CVPIA) in 1992. The CVPIA committed 800,000 acre-feet of annual CVP project water, previously allocated to agriculture, to meet these objectives. A Water Acquisition Program (WAP) was created to acquire additional water supply when needed, and to improve the agency's ability to meet new regulatory water quality requirements under a new Program to Meet Standards. 
Subarea Allocation

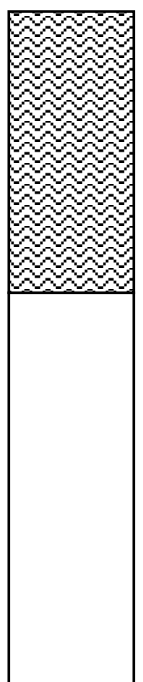

Subarea Load

Consumptive Use Allowance

Measured flow * trigger value

Subarea Base Load Allocation:

Measured flow *

background EC

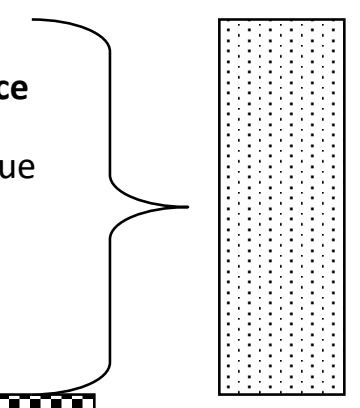

Assimilative Capacity from Subarea

Allocation - Measured Load

\section{Actual Load}

Measured flow * EC

Figure 7. Monthly assimilative capacity calculation for the Stanislaus River sub-area [50]. As with Figure 6 the monthly sub-area load should be compared to the measured salt load. The difference between the sub-area monthly salt load and the monthly allocation is the monthly salt load assimilative capacity that is unused. Hence the Stanislaus River sub-area typically provides more salt load assimilative capacity than it consumes.

These additional project water supply deliveries provide additional assimilative capacity that adds to the USBR's project area salt load allocation [52,53]. Water supply dilution flow allocations were equated to the salt load assimilative capacity provided by this flow as follows:

$$
\mathrm{A}_{\text {dil }}=\mathrm{Q}_{\text {dil }} *\left(\mathrm{C}_{\text {dil }}-\mathrm{WQO}\right) * \mathrm{EC}: \mathrm{TDS} * 0.0013599 \text {, }
$$

where

$\mathrm{A}_{\text {dil }}=$ salt load assimilative capacity allocation provided by dilution flow (tons of salt/month)

$\mathrm{Q}_{\text {dil }}=$ dilution flow volume (acre-feet $/$ month)

$\mathrm{C}_{\text {dil }}=$ dilution flow $\mathrm{EC}(\mu \mathrm{S} / \mathrm{cm})$

$\mathrm{WQO}=$ salinity water quality objective for the LSJR at Airport Way Bridge near Vernalis in $\mu \mathrm{S} / \mathrm{cm}$ EC:TDS $=$ TDS:EC ratio specific to the SJR (0.64). Ratio set to 0.66 for the Merced River and 0.67 for the Tuolumne River

$0.0013599=$ TDS unit conversion factor $(\mathrm{mg} / \mathrm{L}$ to tons/acre-feet $)$

Sub-area allocation calculations are based on the Base Load Allocations and the Consumptive Use Allowance calculations (Figure 6) for the Merced River and Tuolumne River sub-areas. Flow data were obtained from USGS stream gaging stations at Modesto for the Tuolumne River (11290000) and near Stevinson for the Merced River (11272500).

\subsection{Salinity Management Policy Implementation}

Implementation of the salinity TMDL for the SJRB has been constrained by several factors:

(a) The salt load allocation process in the TMDL is complex. Individual sub-areas defined in the TMDL have no easy way to ascertain their contribution to salt loading to the SJR. Assessment of penalties for non-compliance with objectives is not transparent and may be onerous to enforce.

(b) Salt loading is a product of flow and TDS (often measured via EC) and salt load assimilative capacity is a concept that is understood by few stakeholders. There is an educational outreach 
activity needed to address this deficiency and to show the benefits of coordination of activities to improve compliance with salinity objectives.

(c) The TMDL provided no guidance with respect to the formation of an organizational entity with police power for implementing the TMDL or the way a market for salt load trading might be established.

(d) The TMDL was developed using existing agency and stakeholder publicly accessible data. No guidance was provided on the expansion of existing or development of new monitoring networks for additional flow and EC data needed to understand current patterns of salt export from sub-areas within the watershed and for improved salt control and management within each sub-area.

In 2013 the CVWB presented to stakeholders an analysis to partly address criticism of the complexity of the TMDL development process and to provide an incentive to embrace a real-time management program alternative to the formal salinity TMDL accounting procedures. The Real Time (Salinity) Management Program (RTSMP) was introduced in the 2004 CVWB Basin Plan Amendment [52,53] as a stakeholder-driven effort to access shared real-time water quality and flow monitoring data to maximize the use of salt load assimilative capacity in the SJR. The CVWB defined salt load assimilative capacity as $85 \%$ of the product of the prevailing Vernalis salinity objective (30-day running average) and the current flow of the SJR minus the actual salt load in the River (i.e., the current SJR flow times the measured EC at Vernalis). This adaptive approach was suggested as a more flexible alternative to the published TMDL in that it was easier to understand, encouraged more stakeholder coordination for control of salt loading, and promoted maximum export of salt from the Basin while still meeting the stated salinity objective. An upstream SJR objective was added as a further SJRB Water Quality Control Plan Amendment in 2017 to protect SJR riparian diverters in the reach between Crows Landing and Vernalis (Figure 5, Sites 5 and 2, respectively), especially during summer months of dry or critically dry years when river flows are low and salinity levels elevated [53].

Another CVWB action to incentivize consideration of the RTSMP and to provide more clarity to stakeholders was an analysis [54] (Brownell, 2013) that showed a potential fine schedule for non-compliance with sub-area TMDL load limits. This analysis was conducted using available SJR flow and the 30-day running average EC data at the Vernalis compliance monitoring station through the period of record. The period 2001 through 2012 was a period when there were frequent monthly violations of the salinity objectives at Vernalis, as shown in Figure 8. The figure shows the water-year classification over the time period analyzed and the number of times the 30-day running average monthly objective for EC was exceeded during each month. The Grassland sub-area experienced the greatest number of exceedances prior to 2012, primarily during winter and early spring months when runoff from west side agriculture and drainage drawdown from seasonally-managed wetlands (typically February through April) deliver salt loads to the SJR during periods of low SJR salt load assimilative capacity.

In Table 1 the exceedances shown in Figure 8 are translated into hypothetical annual penalties using an assumed USD 5000/day fine that would be applied for the number of days in each the month when the 30-day running average EC was exceeded. The average annual penalty for a sub-area was calculated from the total penalties for the sub-area (total number of daily exceedances multiplied by the daily penalty) divided by the number of years in the analysis [54]. 


\begin{tabular}{|c|c|c|c|c|c|c|c|c|c|c|c|c|c|c|}
\hline \multicolumn{15}{|c|}{ Lower San Joaquin River Salt Discharge Exceedances } \\
\hline $\begin{array}{c}\text { Sub Area } \\
\text { and Period } \\
\text { Studied }\end{array}$ & Water Type Year & Oct & Nov & Dec & Jan & Feb & Mar & Apr & VAMP & May & Jun & Jul & Aug & Sep \\
\hline \multirow{5}{*}{$\begin{array}{r}\text { Northwest Side } \\
\text { (1 Jan 2005- } \\
31 \text { Mar 2012) }\end{array}$} & Wet $\left(3^{a}\right)$ & & $1^{\mathrm{b}}$ of 3 & 1 of 3 & 2 of 3 & & & 2 of 3 & & & 1 of 3 & & & \\
\hline & Above Normal (1) & & & & & & & & & & & & & \\
\hline & Below Normal (1) & & & & & & & & & & & & & \\
\hline & Dry (1) & & & 1 of 1 & 1 of 1 & & & & & & & & & \\
\hline & Critical (2) & & 2 of 3 & 2 of 3 & 3 of 3 & 1 of 3 & & & & & & & & \\
\hline \multirow{5}{*}{$\begin{array}{l}\text { Grassland } \\
\text { (1 Jan 2002- } \\
31 \text { May 2011) }\end{array}$} & Wet (3) & & & 3 of 3 & 3 of 3 & 1 of 3 & 2 of 3 & 3 of 3 & & & 1 of 3 & & & \\
\hline & Above Normal (1) & & & 1 of 1 & 1 of 1 & & 1 of 1 & & & & & & & \\
\hline & Below Normal (2) & & 1 of 2 & 2 of 2 & 2 of 2 & 2 of 2 & 2 of 2 & & & & & & & \\
\hline & Dry (2) & & & & 2 of 2 & 2 of 2 & 2 of 2 & & & & & & & \\
\hline & Critical (2) & & 1 of 2 & 2 of 2 & 2 of 2 & 2 of 2 & 2 of 2 & 1 of 2 & & & & & & \\
\hline \multirow{5}{*}{$\begin{array}{l}\text { SJR Upstream } \\
\text { of Salt Slough } \\
\text { (1 Jan 2001- } \\
30 \text { Sept 2010) }\end{array}$} & Wet (2) & & & & & & & & & & & 1 of 2 & 2 of 2 & \\
\hline & Above Normal (1) & & & & & & & & & & & & & \\
\hline & Below Normal (2) & & & & & & & 1 of 2 & & 1 of 2 & 2 of 2 & 2 of 2 & 2 of 2 & \\
\hline & Dry (3) & & & & & & & 1 of 3 & & 1 of 3 & 3 of 3 & 3 of 3 & 2 of 3 & \\
\hline & Critical (2) & & & & & & & 1 of 2 & 1 of 2 & 1 of 2 & 2 of 2 & 2 of 2 & 2 of 2 & \\
\hline \multirow{7}{*}{$\begin{array}{c}\text { East Valley } \\
\text { Floor } \\
\text { (VAMP/2005- } \\
31 \text { Dec 2007) }\end{array}$} & Wet (2) & & & & & & & & & & 1 of 2 & 1 of 2 & & \\
\hline & Above Normal $(0)$ & \multirow{3}{*}{\multicolumn{13}{|c|}{ No Data Available for this period }} \\
\hline & Below Normal $(0)$ & & & & & & & & & & & & & \\
\hline & Dry $(0)$ & & & & & & & & & & & & & \\
\hline & Critical (1) & & & & & & & & & & & 1 of 1 & 1 of 1 & \\
\hline & a Number of water typ & e years & & & & & & & & & & & & \\
\hline & b Number of years the & $t$ the se & dic & $\operatorname{arge~e}$ & eeded th & he mo & thly all & o & & & & & & \\
\hline
\end{tabular}

Figure 8. Enumeration of monthly SJR salinity objective exceedances of the $700 \mu \mathrm{S} / \mathrm{cm}$ irrigation season and $1000 \mu \mathrm{S} / \mathrm{cm}$ non-irrigation season salinity objective at Vernalis for the period of record (column 1) through 2012 [34]. Color ramp from blue to red indicates water year type that ranges from wet (blue) to critically dry (red) according to the State of California San Joaquin River index. The Vernalis Adaptive Management Program (VAMP) was active during this period and provided scheduled fishery flows in the LSJR between 15 April and 15 May each year [54].

Table 1. Schedule of potential annual average penalties between 2001 and 2012 that could have been assessed for exceedances of salinity objectives at Vernalis under the salinity TMDL, assuming a hypothetical penalty of USD 5000/day for each monthly overage [54]. Northwest side (NWS); Grassland (GL); Upstream San Joaquin River (SJR), East Valley Floor (EVF).

\begin{tabular}{|c|c|c|c|c|c|}
\hline \multicolumn{6}{|c|}{ Potential Salt Discharge Load Exceedance Fees by sub-area (2001-2012) } \\
\hline \multicolumn{2}{|c|}{ Sub-area } & \multirow{2}{*}{$\begin{array}{c}\text { NWS } \\
0\end{array}$} & \multirow{2}{*}{$\begin{array}{c}\text { GL } \\
0\end{array}$} & \multirow{2}{*}{$\begin{array}{c}\text { SJR } \\
0\end{array}$} & \multirow{2}{*}{$\begin{array}{c}\text { EVF } \\
0\end{array}$} \\
\hline \multirow{13}{*}{ Days exceeded by period } & October & & & & \\
\hline & November & 90 & 60 & 0 & 0 \\
\hline & December & 124 & 248 & 0 & 0 \\
\hline & January & 186 & 0 & 310 & 0 \\
\hline & February & 28 & 196 & 0 & 0 \\
\hline & March & 0 & 279 & 0 & 0 \\
\hline & April & 28 & 56 & 42 & 14 \\
\hline & VAMP & 0 & 0 & 30 & 30 \\
\hline & May & 0 & 0 & 51 & 17 \\
\hline & June & 30 & 30 & 210 & 90 \\
\hline & July & 0 & 0 & 248 & 91 \\
\hline & August & 0 & 0 & 248 & 31 \\
\hline & September & 0 & 0 & 0 & 0 \\
\hline \multicolumn{2}{|c|}{ Total days of exceedances } & 486 & 869 & 1139 & 273 \\
\hline \multicolumn{2}{|c|}{ USD 5000 per day penalty } & USD 5000 & USD 5000 & USD 5000 & USD 5000 \\
\hline \multicolumn{2}{|c|}{ Total penalties } & USD $2,430,000$ & USD $4,345,000$ & USD 5,695,000 & USD $1,365,000$ \\
\hline \multicolumn{2}{|c|}{ Years calculated } & 8 & 10 & 10 & 3 \\
\hline \multicolumn{2}{|c|}{ Average penalty per year } & USD 303,750 & USD 434,500 & USD 569,500 & USD 455,000 \\
\hline \multicolumn{2}{|c|}{ Sub-area acreage } & 118,000 & 353,000 & 187,000 & 201,000 \\
\hline \multicolumn{2}{|c|}{ Average penalty per acre } & USD 2.57 & USD 1.23 & USD 3.05 & USD 2.26 \\
\hline
\end{tabular}


The average annual penalty was also divided by the sub-area area (acres) to obtain an annual average penalty per acre [54]. The average annual sub-area penalties of USD 303,750 and USD 569,500 per year, equivalent to USD 1.23 and USD 3.05 per acre per year (Table 1), are powerful incentives for agricultural and wetland stakeholders to seek an alternative regulatory salinity management solution such as the option to embrace Real-time Salinity Management (RTSM).

\subsection{Real-Time Salinity Management Program (RTSMP)}

Salinity management in the SJRB is complex, involving agricultural, wetlands, and municipal stakeholders within the Basin and interested environmental groups and municipal entities downstream in the San Francisco Bay Area. The concept behind the RTSMP is to use existing or anticipated salt load assimilative capacity generated by dilution flows to increase the export of salt load from the Basin, when available, and to improve the scheduling of salt load discharge into the River or temporary storage facilities when salt load assimilative capacity is more limited or not available [55]. This could be extended to scheduling additional dilution flow releases such as those provided by the USBR through New Melones Reservoir and the Stanislaus River. Stakeholders from water districts that rely on New Melones Reservoir for a portion of their water supply have been supportive of the RTSMP concept, since optimized control of salt discharged to the River from upstream sources would likely reduce the draw on New Melones Reservoir for water quality purposes. The CVWB prescribed the requisite components of a successful RTSMP as follows [52] (CVWB, 2004):

(a) The Program maintains and (where necessary) expands existing accessible real-time monitoring networks that measure flow and EC necessary to assess daily SJR salt load assimilative capacity. The sharing of private water district drainage flow and EC data, as well as diversion data for those riparian districts that utilize the SJR for irrigation water supply, helps to expand the current environmental sensor network and is an important way the agricultural and wetland entities can show their commitment to the RTSMP.

(b) The Program provides technical support of the RTSMP that includes the development and maintenance of a computer-based water quality simulation model that can be used to estimate salt load assimilative capacity in the SJR. The simulation model would accommodate the inclusion of real-time drainage and SJR diversion data from cooperating stakeholders. The model would make 14-day forecasts of SJR flow, EC, and salt load assimilative capacity based on advance schedules of east side tributary reservoir releases and other planned operations such as district diversion pumping schedules. Where these advance schedules are not available, archived data that match time of year and water-year type can be used by the model to make provisional forecasts.

(c) An accessible data repository is a necessary feature of the Program that archives sensor network data and a data screening capability to provide a minimum level of data quality assurance and control. Several of the larger water districts and water agencies use hydrological data management software such as WISKI and HYDSTRA, (https://www.kisters.net) and AQUARIUS (https://aquaticinformatics.com/products to perform real-time quality assurance on data downloaded from their sensor networks.

(d) The Program will benefit and require the construction of physical infrastructure, such as temporary holding ponds, drainage control structures, and drainage reuse and recirculation systems at the water district or sub-basin watershed level to provide rapid response to periods of potential non-compliance with salinity objectives.

\subsection{Real-Time Salinity Monitoring and Estimation of Salt Load Assimilative Capacity}

Over the past decade there have been significant technology improvements in the accuracy and reliability of flow and water quality sensors and sondes and in Web-based data accessibility. Rotary wipers now allow the efficient maintenance of sensor electrodes, permitting sondes to be 
deployed longer between service quality assurance checks [56]. Calibration procedures are now built into the software of these instruments, reducing the time needed to perform these checks. Data telemetry hardware and programming software procedures have also become more plug-and-play and, at the same time, cellular data service plans have become much more affordable. Most of the current data logger/modem devices on the market also allow two-way communication, overcoming a long-standing limitation of the GOES satellite radio communication system that has been popular with water agencies because of its low cost. Real-time data access has also undergone significant improvement with vendor-supported Web portals now available at low cost to store and allow flexible visualization of real-time and archived data. More recent data logger innovations now allow some basic arithmetic operations to be conducted on the collected data, such as calculation and display of salt loads after combining flow and EC data. Several vendors are also exploring adding basic data quality assurance functionality to their data loggers by allowing access to basic Python scripting functions.

\subsection{Real-Time Salinity Modeling and Forecasting}

Model-based forecasting of salt load assimilative capacity requires ready access to current flow and EC data within the SJRB and an underlying hydrology and water quality simulation model to relate these data to flow and salinity at the two SJR compliance monitoring stations. The model should be watershed-based if on-farm and water-district-led management strategies for control of salt export are to be assessed. The Watershed Management Risk Management Framework (WARMF) model [57-59] is a comprehensive decision support tool that was designed specifically to facilitate TMDL development at the watershed-level and that has been applied to facilitate RTSM in the SJRB. The model performs mass balances for a large suite of potential SJR contaminants including total dissolved solids (measured as EC), suspended solids, phosphates, and nitrates and simulates SJR tributary inflows from the major east side rivers, riparian, and appropriative diversions. The model also estimates agricultural and wetland drainage return flows and calculates likely accretions from shallow groundwater along the SJR (Figure 9). The WARMF model uses hydrologic routing to calculate flow and water quality at approximately one-mile intervals along the main stem of the SJR. For the purposes of the RTSMP only the flow and salinity outputs of the model are critical.

Wetland drainage from the Grassland Ecological Area (a 140,000-acre tract in the Grassland sub-area) is similarly partitioned into individual watersheds representing the state, federal, and private wetland sub-areas contributing to SJR salt load [56,58]. The GIS-based WARMF model graphical user interface (GUI) allows easy visualization of WARMF model flow and salinity input data. Spreadsheet-like data templates are accessible to store data downloaded daily from state and federal agency hydrology and water quality databases to provide automated updating of model input files and to keep the WARMF model current. Customized output graphical displays such as the Gowdy Output (Figure 10) provide the user with a powerful tool to interpret WARMF-SJR model simulation results and to toggle between daily flow, EC, and salt load for the 60-mile SJR reach between Lander Avenue and Vernalis. On the left panel, inflow to the SJR is depicted as green horizontal bars superimposed over the inflow source label, whereas diversions from the SJR are depicted as red horizontal bars to the left of the vertical axis. The uppermost panel on the right displays SJR travel time with a starting value of 1.8 days that declines to zero days at the Vernalis compliance monitoring station for EC. SJR flow is displayed in the same panel increasing from left to right, incrementing in steps at the points of confluence with the three east side tributaries. The lower right-hand panel shows cumulative SJR flow relative to cumulative SJR diversions at the intakes to West Stanislaus, Patterson, and El Solyo irrigation districts. The Gowdy Output (Figure 10) also provides the user with a detailed snapshot of past and current flow and water quality conditions in the SJRB [38] by using the daily date dialog box located on the upper left of the figure. 


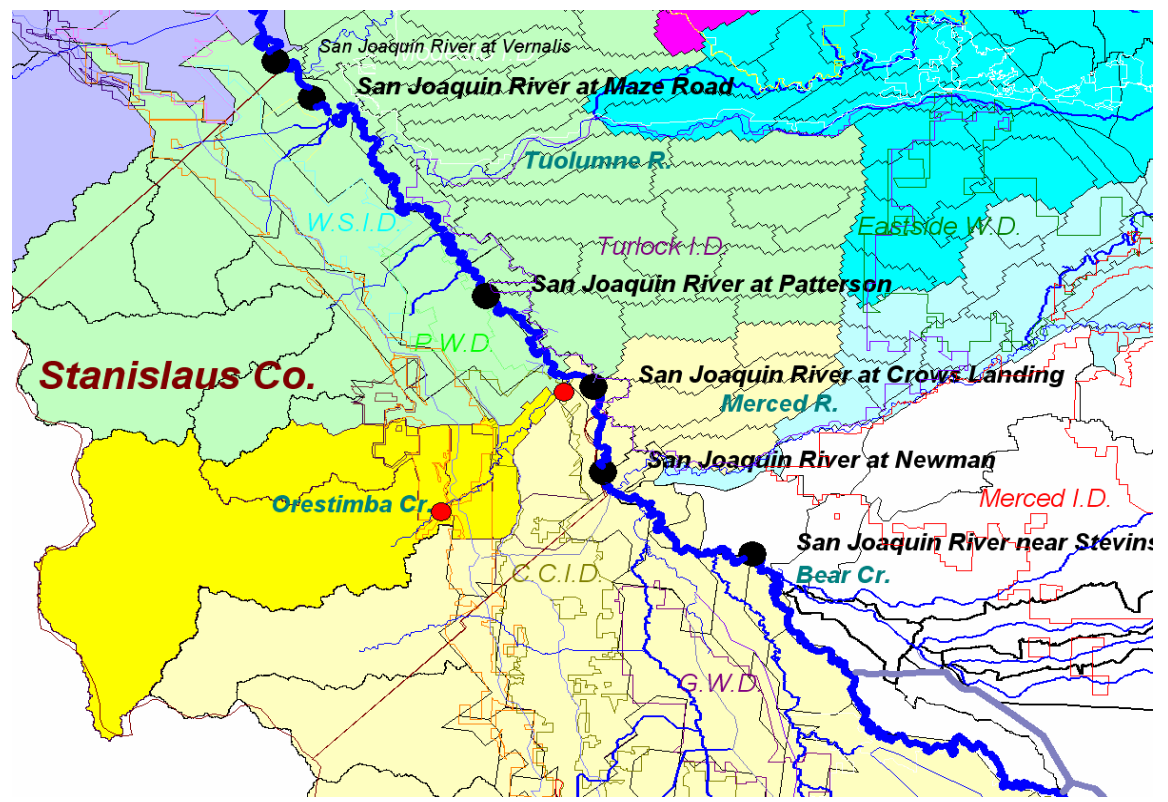

Figure 9. The Watershed Analysis Risk Management Framework-San Joaquin River (WARMF-SJR) model user interface showing the disaggregation of minor watersheds within each major sub-area that contribute flow and salt load to the SJR. The political boundaries of individual agricultural water districts are the most appropriate management entities for monitoring, management, and control of salt loading to the SJR from each west side sub-area.

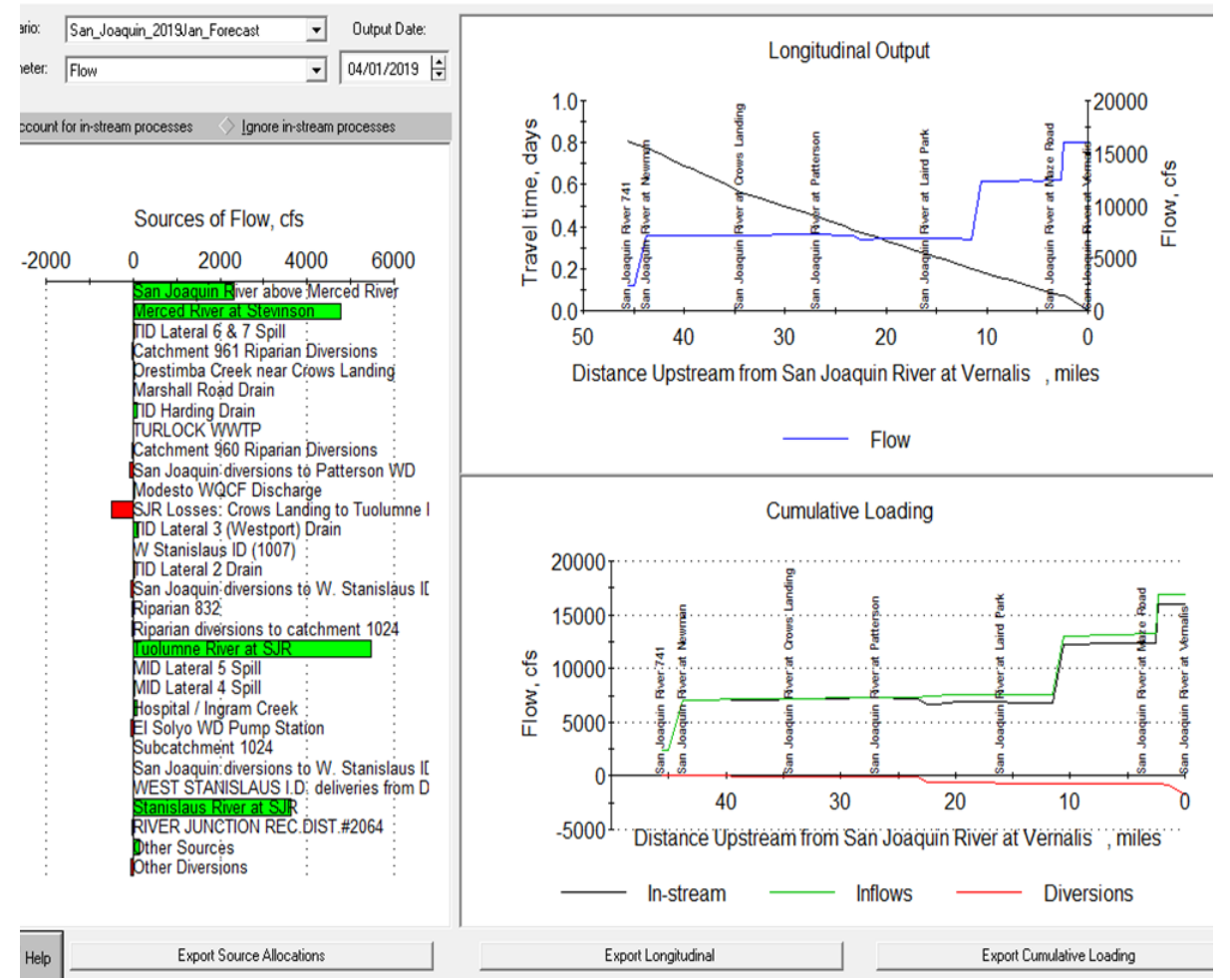

Figure 10. Customized WARMF model Gowdy output showing (left panel) daily SJR inflows and diversions every mile $(1.6 \mathrm{~km})$ for the mainstem of the SJR [58]. Output is for a single day and date that can be incremented or decremented in the upper left dialog box. Upper right panel shows both travel time from Lander Avenue and cumulative flow increases from Lander Avenue to Vernalis. The lower right panel shows cumulative flow and cumulative diversions. Other panels (not shown) show EC and cumulative salt load along the same reach of the River. 


\subsection{Web-Based WARMF Model Data and Model Forecast Visualization for Sustainable Real-Time Salinity Management}

The concept of RTSM is most readily facilitated when all stakeholders have an easy way to access and process real-time data and make short-term reliable forecasts that inform management decisions and operations [59]. The RTSMP began development of a comprehensive resource in 2014-the San Joaquin River Real Time Management (SJRRTM) Online Web portal that provides real-time access to a comprehensive array of watershed flow and EC data (Figure 11), WARMF model data input, and 14-day forecasts of SJR salt load assimilative capacity. The SJRRTM Web portal was designed to enhance stakeholder awareness of the current status of water and water quality conditions in the SJR and to support collaborative actions to enhance salinity management decision-making. The Web portal also provides stakeholders access to information resources (reports, GIS, data sets) and other reporting dashboards for viewing WARMF model output. A goal of the SJRRTM Web portal was to provide water district managers and those responsible for coordinating sub-area salt loading with the tools for anticipating salt loading schedules so that they could be matched with scheduled or forecast reservoir releases of dilution flows from the east side tributaries [59].

The Web portal was implemented using the open-source OpenNRM software, a suite of software tools developed by 34 North Inc. [59]. The OpenNRM software tools allow users to create, modify, and manage data and Web content systematically and also provide content filtering capability to organize information based on subregion boundaries, specific areas of interest, and personalized data dashboard selections. One of the unique features of the SJRTM Web portal has been the integration of real-time SJR and tributary flow and EC data with WARMF model-generated flow, salinity, and salt load assimilative capacity forecasts-these are rarely supplied on a common platform. The assembled data sets were reformatted and aligned by the OpenNRM client software for direct import into the WARMF model for forecasting purposes and to the customizable data reporting dashboards. The OpenNRM software was also configured to supply relevant baseline data for those only interested in running the WARMF model and making model-based forecasts-accessed through a separate Web portal tab. One stakeholder client was sufficiently enamored by the customizable data dashboard capability to engage the OpenNRM developer to create a custom application to support her individual water-quality-related oversight responsibilities, which hitherto had required tedious visitation of multiple agency websites and those of other data providers.

Despite the unique capabilities of the SJRRTM Online Web portal to help visualize and operationalize current SJRB data in combination with the WARMF model for salinity compliance assessment and decision support, the tool has not enjoyed the level of support anticipated among SJRB stakeholders. Reasons may include

(a) The Web portal is comprehensive and allows easy access to all current, publicly accessible real-time flow and EC data, however, stakeholder feedback suggests that the Web portal is hard to navigate and there are often too many steps involved in accessing specific data. Although one stakeholder invested time and effort in building a custom dashboard with URL links to data she used routinely others appeared less willing to commit the time. This can be ascribed to the fact that their data access needs were less prescribed and more random - the productivity gains they anticipated from use of the tool were lower than expected by the development team.

(b) There are no current financial incentives with respect to salinity non-compliance that might encourage stakeholders to take advantage of the resources offered by the SJRRTM Online Web portal. During periods of non-compliance the imposition of fees associated with salt loads in excess of sub-area monthly salt load targets would likely incentivize the quantification of salt loads and salt load assimilative capacity and comparisons between monthly sub-area salt load targets and sub-area performance with the SJRB. 


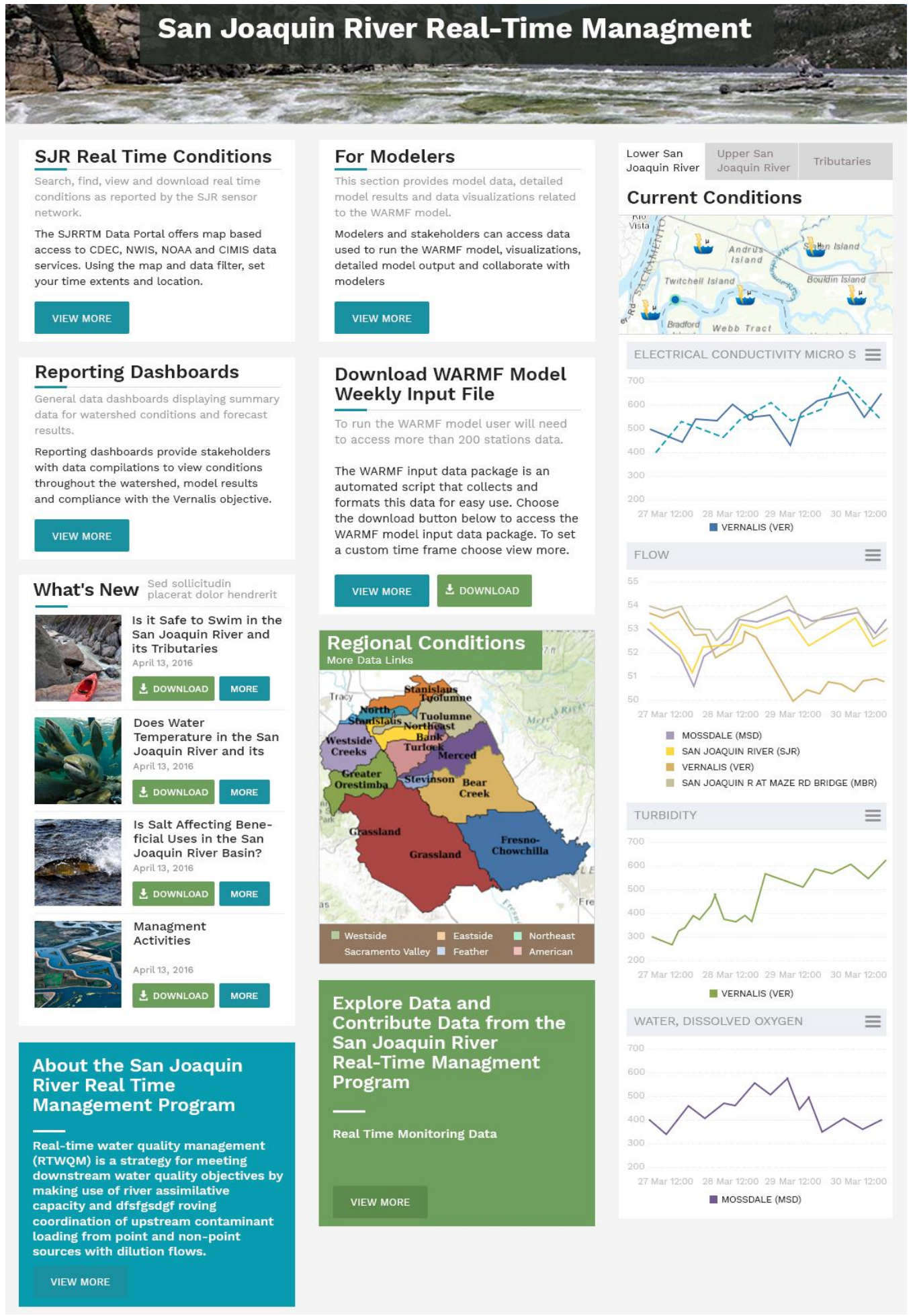

Figure 11. Display of the SJR Real-Time Management Online Web portal built using the 34-North OpenNRM visualization software toolbox. The Web portal provides dashboard access to available SJR-related data as well as WARMF model input and salt load assimilative capacity forecast output. It is a "one stop shop" for all data related to the SJR.

\subsection{Alternative Modeling Approaches for Sustainable Real-Time Salinity Management}

The WARMF model has provided a scientifically defensible framework for analysis of SJR flow and salinity data primarily from west side agricultural drainage and for developing watershed-based 
forecasts of short-term salt load assimilative capacity for sustainable SJR salinity management. Sustainable SJR salinity management is equated to compliance with current SJR salinity objectives at the Vernalis, Crows Landing, and, most recently, Maze Road compliance monitoring sites. Salt load assimilative capacity forecasts require the provision of both current (real-time) flow and salinity data as well as information on anticipated actions impacting SJR flow and salinity over the chosen, two-week forecast period. The accuracy of these forecasts is typically a function of the level of stakeholder involvement and the sharing of information. The WARMF watershed-based forecasting model approach allows SJRB stakeholder entities responsible for regulatory compliance to recognize individual sub-area salt load discharges over and above allowable load limits during periods of insufficient SJR salt load assimilative capacity. The WARMF model armed with these salt load assimilative capacity forecasts can be run to assess the most cost-effective and politically expedient actions for resolving these periods of potential overage before they occur. In general, the 30-day running average EC objective at the Vernalis compliance monitoring site is most likely to be exceeded during the months of late March, April, and May when seasonally managed wetlands discharge to the SJR and upstream reservoirs are actively filling, providing diminished dilution flow. While supporting WARMF model routine forecast activity, the USBR recognized the need for a more easily automated screening-level decision support tool for the majority of time periods when no remedial action may be necessary. It was recognized that with climate change and the propensity for extreme events and more severe drought events the incidence of stress on SJR salt assimilative capacity may increase over time. This novel hybrid approach to salinity forecasting in the SJR undertaken by the USBR was based on a data-driven regression model that relates flow to EC using an inverse gradient algorithm (Figure 12). This screening-level approach for estimating EC has been applied to the Vernalis, Crows Landing, and Maze Road compliance monitoring stations on the SJR [60].

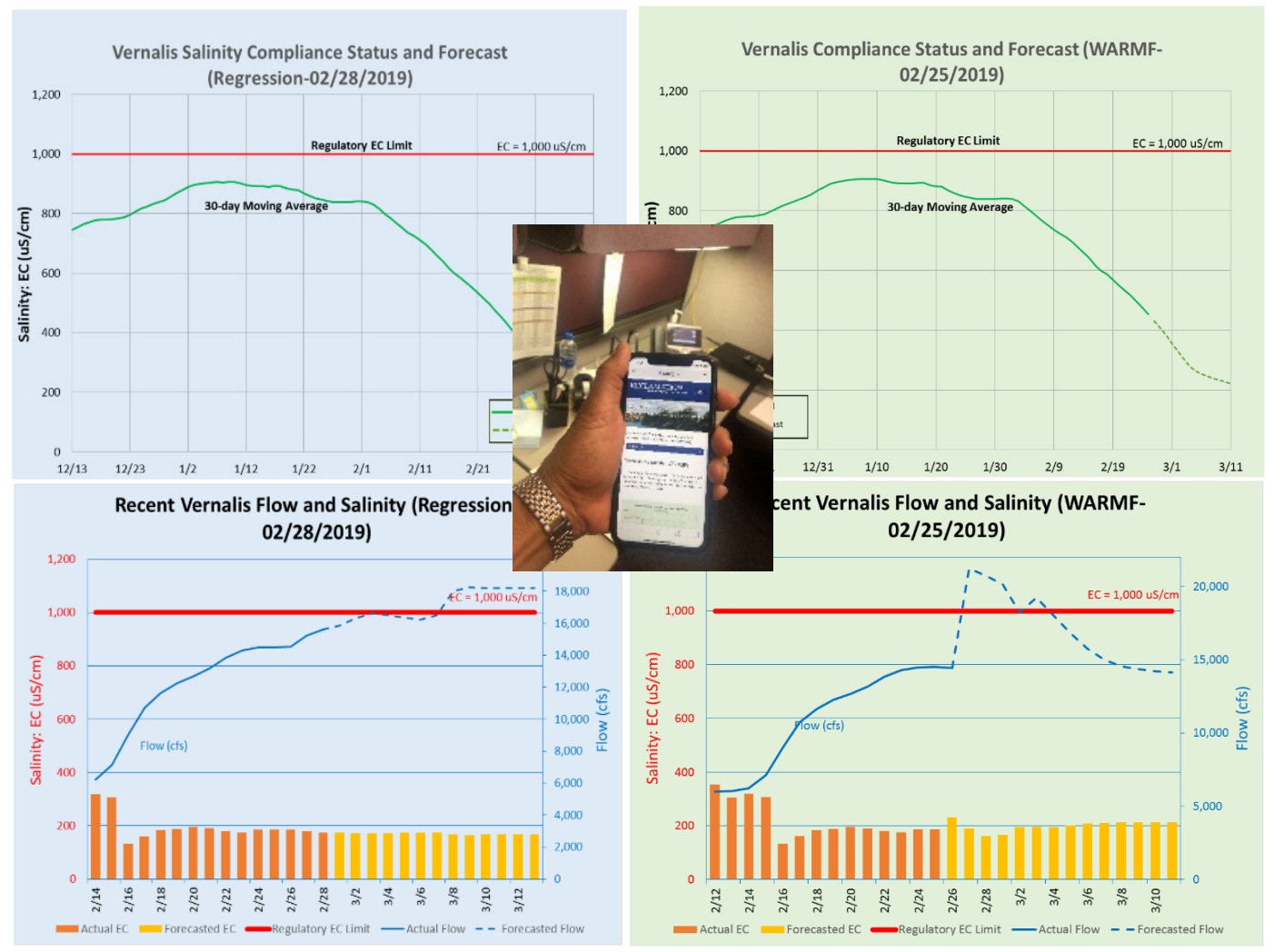

Figure 12. Comparison of regression-based (left panels in blue) and WARMF-based (right panels in green) real-time salinity forecasting models. Inset (middle) shows the smartphone RTSM screening model interface that allows stakeholders to readily view both regression model and WARMF model forecasts [58]. 
The basis for the inverse gradient regression model was the observation that: (a) EC decreased when stream flow increased, and vice versa; and (b) the EC's rate of change was proportional to the River's change in flow rate. The inverse gradient regression model has yielded good forecast accuracy for EC and salt load, especially when paired with independent 10-day SJR flow forecasts made daily by the NOAA River Forecast Center [60]. One distinct advantage of this data-driven regression model approach has been the time savings compared to the setup and execution of the WARMF model forecast simulations and the time associated with WARMF model data updating and model maintenance. Preliminary results, based on flow and EC data for the years 2004 to 2019, indicated that the regression model performed as well as the WARMF model for forecasting EC at the Vernalis and Crows Landing compliance monitoring stations (Figure 11). This screening-level approach can be used to alert stakeholders to conditions where EC forecasts approach the EC compliance objectives at either site, which might warrant intervention to actively manage salt loading to the River. In such situations the WARMF basin-scale model aids stakeholders by providing estimates of load contributions from each of the seven sub-areas contributing salt load to the SJR. Awareness of current salt loading from each of these sub-areas and comparison of these loads to those allowable under the salinity TMDL for each sub-area allows more targeted interventions.

\subsection{Case Study of the Hunter River Salinity Trading Scheme}

The goal of simplifying and making more intuitive the forecasting model interface to end users has an inspiring exemplar in the Hunter River Salinity Trading Scheme (HRSTS) in New South Wales, Australia (Figure 13). This is a stakeholder-led licensing scheme to manage discharges of salt load in the Hunter River Basin primarily from mines and power stations that discharge into the River, and it was compared to an earlier iteration of the RTSM program in a study $[59,61]$ that examined the policy goals and directives and implementation success of the two systems. Like the RTSM program, the HRSTS relies on a comprehensive network of real-time monitoring stations that keep track of daily discharge and salt loading to the Hunter River and ambient river conditions. Although hydrological and water quality models of the Basin exist, the main "workhorse" of the HRSTS is a simple accounting spreadsheet called the River Register that was operated by the Department of Natural Resources and funded by stakeholders who kept daily track of these flows and salt loads. The simple website provides ready access to the credit register and other information on the HRSTS as well as current salt load account balances for registered scheme members. A simple freight train and boxcar analog is used to explain the scheme, asking stakeholders to visualize a series of boxcars, each containing salt, that can be filled to a daily limit established by the assimilative capacity of the train (River) during each 24-h period [61]. Each stakeholder can trade a portion of his/her allocation for the right to load salt onto the boxcar. Following the boxcar analog, the Hunter River was notionally divided into "blocks" where each block represents a portion of the River (boxcar) predicted to pass a designated gaging station (Singleton) on the Hunter River within a 24-h period (Figure 13).

Salt management policy provides a very simple method for managing discharge into the River by classifying each block with respect to the reach (sector) of the River it passes through, using the following designations:

- low flow-discharges not allowed,

- high flow-discharges allowed using tradeable salt load credits,

- flood flows-no limit to salt load unless restricted under a policy provision.

During high flow events, stakeholders can discharge a salt load expressed as a share of the total allowable daily discharge for each block according to the number of salt credits, out of the 1000 available each day, that they own. Hence, each credit entitles a stakeholder to a salt load discharge equivalent to 1/1000 of each high flow day's total allowable discharges. Credits are tradable on the HRSTS River Register to ensure salt loads are managed in an efficient and cost-effective manner and that river water quality goals are met sustainably according to national and state salinity management policy [61]. 


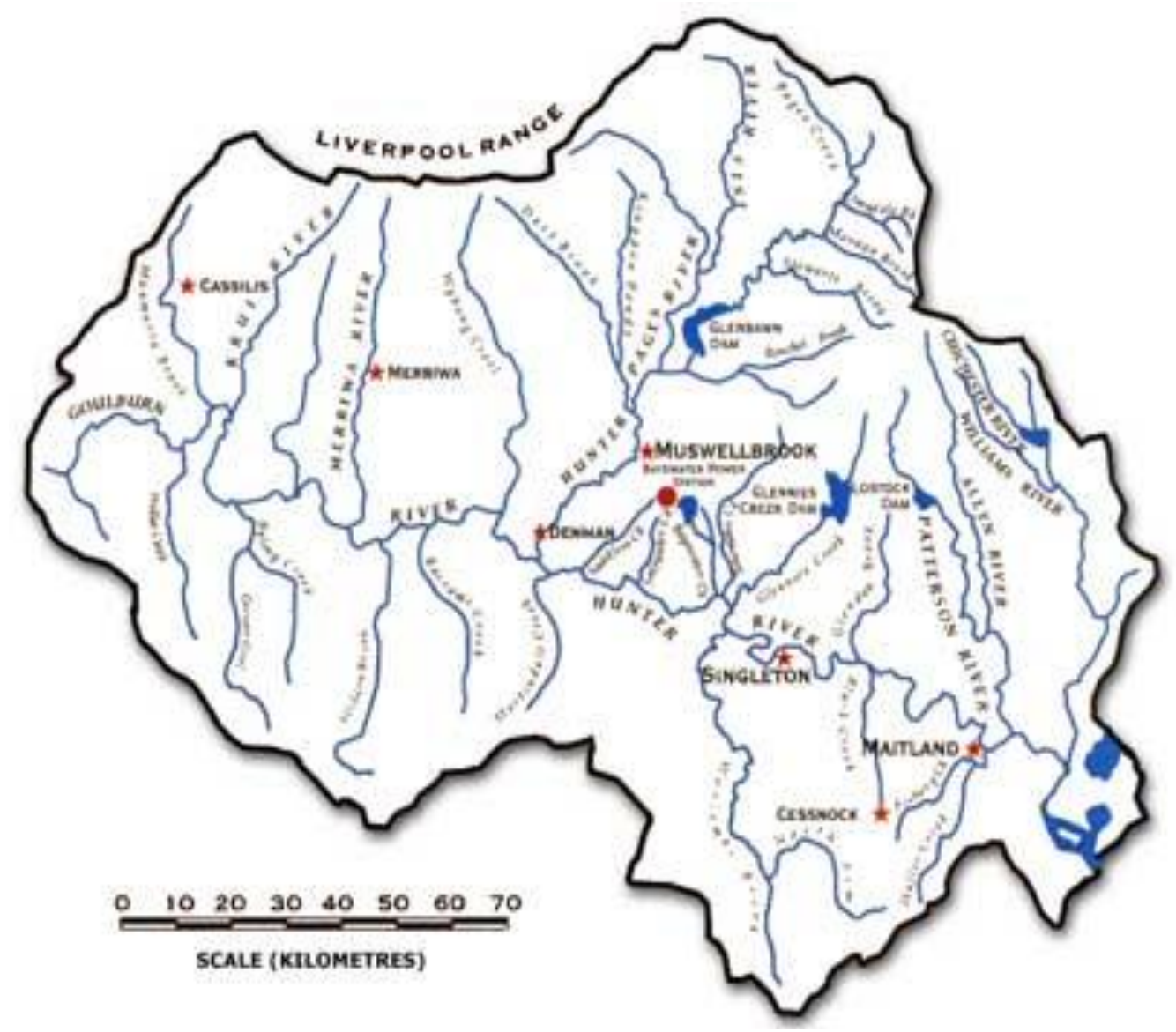

Figure 13. Hunter River Basin in New South Wales, Australia, which adopted a more stakeholder-centric policy for control of a salt management system that relies on real-time sensor networks and greater local coordination and cooperation [61,62].

Although the Hunter River Basin example is much smaller in scale and involves only two major stakeholder groups-miners and power plant operators-as opposed to the more diverse stakeholder population of irrigated agriculture, urban/municipal and environmental interests at play in the SJRB, the contrast in implementation effectiveness and potential sustainability is instructive. In the SJRB river assimilative capacity is estimated daily using a similar real-time sensor network, although there was no provision to pull together the disparate elements of this network until the SJRRTM Web portal was developed. The highly disaggregated and ambitious goals of the Web portal have made it difficult to support financially and maintain. In the HRSTS the salt load assimilative capacity of the River is strictly tied to river flow and the allocation of load clearly defined according to the low/high/flood flow designations and the market-based trading system. In the SJRB water flow and quality from all sources are combined daily to assess salt load assimilative capacity, and there is no current mechanism for managing load over and above the CVWB TMDL and real-time allocations. Calculation of these daily allocations, as was demonstrated earlier, is complicated and, even with powerful visualization tools, is not provided in a decision support context that allows successful implementation and the potential for sustainability as described in the HRSTS. There is also a sociological aspect of cooperation and collaboration, which is, in part, tied to the size of the stakeholder group [61]. The evidence of greater trust and degree of cooperation between landowners, resource management advisers, and regulators in the Hunter River Basin allows stakeholders to achieve their salt management goals with a simple and robust accounting system. 


\section{Discussion}

This paper focused on irrigation sustainability of agriculture on the west side of the SJV and the SJRB - the west side of the SJRB is that subregion within the SJV that drains to the SJR and, hence, to the Sacramento-San Joaquin Delta and San Francisco Bay. The SJRB is an exemplar of the conflicts that occur around the world between agricultural, urban/municipal, and environmental users of scarce water supply and, hence, is well suited for an exploration of evolving policy interventions and how these options have led to the desired level of environmental protection. This paper started out by noting that there are two component resource constraints to agricultural irrigation sustainability-these are the provision of an adequate water supply and the provision of a water supply of sufficient quality, typically measured in terms of salinity, to achieve sustainable crop yields. This paper then discussed each of these constraints in turn, showing and discussing how policy has addressed the unregulated extraction of groundwater in the 30 years since the first adoption of the groundwater turbine pump in the 1920s. The paper described how this technology innovation led to a massive replumbing of the water supply delivery system in the SJV and SJRB, which in turn introduced a new set of environmental problems. Those are now associated with water quality-primarily salinity in the case of agricultural beneficial use of this water supply.

In the paper we also described a reemergence of many of the problems that were largely solved by investments in the water supply infrastructure provided by the federal CVP San Luis Unit until a sequence of crippling droughts in California triggered a surge in (still unregulated) groundwater development. This market-driven response to the drought brought back some of the same regional subsidence problems and damage to critical water supply infrastructure. However, this time the rates of land surface deformation and subsequent damage were more localized and more costly to contain. Research by the U.S. Geological Survey and others has shown that the majority of this subsidence [7] occurred in the interbeds below the Corcoran Clay and not in the clay itself, as in the previous case in the 1930s. Another wave of policy interventions, this time accompanied by legislation in the form of the SGMA and without the promise of a replacement water supply, charged stakeholders with the responsibility for both improving their understanding of the limits of their groundwater resource and developing their own constraint mechanisms to limit future groundwater extraction for long-term sustainability. Since agriculture dominates land use and groundwater supply utilization in the SJRB, the decisions made within the GSAs formed under SGMA will have profound impacts on the future of irrigated agriculture in the Basin. These decisions are also likely to impact the second rail of sustainable irrigation agriculture in the Basin-that of water quality. Surface and groundwater are now recognized as a single resource not only in state environmental and resource management policy but also in the models that are continuously under development in the state and federal water resource agencies, the USBR and the California DWR. The paper, while applauding this new "one-water" mantra by water resource agencies, laments the fact that we are still some way from having a universally accepted tool for surface and groundwater resource planning in the state [19], although a recognition of the limitations of these tools is a necessary first step in overcoming them. Although water quality impacts are certainly likely with SGMA it is also clear that these modeling tools-CVHM and C2VSIM-are not currently capable of providing long-term decision support for water quality and guiding decisions for irrigated agriculture sustainability.

The second part of the paper provided an overview of water quality (primarily salinity) constraints to irrigated agriculture and of the limitations of our knowledge and ability to perform salt management at the farm and regional scales. The paper advances the thesis that it was the selenium crisis at Kesterson Reservoir and its aftermath that permanently changed the relationships between irrigated agricultural, municipal/urban, and environmental resource advocates, which has been the genesis of much environmental regulation aimed at drainage return flow impacts on the environment. The policy response in this case was to embark on a massive research and information gathering mission led, primarily, by researchers within the University of California system and funded by federal and state water resource agencies. The most significant of this multi-agency effort was the federal SJVDP, 
which pulled in researchers from state and federal water agencies as well as those concerned with fish and wildlife resources and completed its policy and planning roadmap in September 1990 [26]. Although the accomplishments of this joint effort under the UC Salinity Drainage Program were significant, implementation of the recommendations of the SJVDP plan did not follow. California irrigated agriculture entered a holding pattern through the subsequent jointly funded San Joaquin Valley Drainage Implementation Program (1991-1999) and the federal San Luis Drainage Feature Reevaluation (2007) [63]. It was not until CVWB approval of the initial salinity and boron TMDL in 2002 that any real progress was made at setting targets and constraints of drainage salt loading. The political response by irrigated agriculture advocates to the TMDL was largely muted by the years of defensible research that occurred under the SJVDP and consequent programs that were mostly focused on selenium drainage. The response was also influenced by the early successes of the Grassland Bypass Project (GBP) (1996-2019) $[64,65]$ which showed that agricultural water districts located in the 100,000 acre sub-area most affected by selenium drainage were capable of real-time management of selenium drainage through adaptive irrigation and drainage management $[66,67]$. These Grassland sub-area drainage entities were able to meet every monthly and annual selenium load target set by the Use Agreement for interim use of the San Luis Drain for drainage conveyance, except during the first two years of the project in 1996 and 1997 when back-to-back El Niño storm events caused widespread flooding and inundation. A more detailed description of the Grassland Bypass Project and the San Joaquin River Improvement Project (SJRIP) reuse area and facility, used to dispose of selenium and salt loads that would otherwise have discharged into the SJR, is provided in an unpublished companion paper in this same Special Issue of Sustainability [68].

Adoption of RTSM as a whole-basin alternative to a more restrictive and resource-inefficient salinity TMDL achieved some early success in the SJRB. However, long-term implementation of the concept will require a high level of cooperation and coordination, which hitherto has not existed in the Basin, unlike the Hunter River Basin in New South Wales, Australia, where real-time salinity management was achieved with a much simpler, less cybertechnology- and monitoring-intensive approach [59]. This was ascribed to higher levels of interaction and corporation between regulators, government extension specialists, and landowners, and a simple conceptual model of salt load management and Hunter River assimilative capacity using a boxcar analogy that all involved were able to understand. Realization of the full potential of RTSM will require the formation of a basin-scale, stakeholder-led salinity management entity with the authority and police power to enforce compliance with river water quality objectives and to impose penalties on stakeholder coalitions representing stakeholders within each sub-area. In the SJRB two major agricultural coalitions exist representing stakeholders on the east and west sides of the SJR. These existing coalitions could play a more active role, not only in the funding and maintenance of flow and EC sensor networks and implementation of a data quality assurance program, but also in coordinating salt load management actions within each sub-area and between sub-areas. The CVWB envisaged a marketplace for salt load discharge to the SJR, similar to the carbon offsets that can be purchased by $\mathrm{CO}_{2}$ emitters who need to reduce their carbon footprint. This would help reduce reliance on New Melones Reservoir for the release of flows for salinity dilution purposes [59], allowing more efficient allocation of water resources to junior water-right stakeholders who typically receive less than their contract water supply from the USBR. An entity known as the SJV Drainage Authority currently exists and is financed by west side SJRB stakeholder contributions and retains a staff to oversee the activities of west side agricultural, wetland, and municipal dischargers of salt and other contaminants into the SJR. This Drainage Authority's role might be expanded to include east side SJRB districts to fulfill the coordination and compliance enforcement activities identified above. Long-term implementation of RTSM will ultimately require coordination of both drainage return flows and reservoir releases from east side tributaries, synthesis of real-time data, computer-based modeling of real-time salt load assimilative capacity, and effective dissemination of daily salt load assimilative capacity forecasts for the SJR [59]. 


\section{Summary and Conclusions}

Salinity problems on the west side of the SJV and, in particular, in the SJRB were exacerbated in the 1960s with the development of the federal San Luis Unit of the CVP that substituted west side diversions from the SJR for pumped water from the Sacramento-San Joaquin Delta. This alleviated, for a period, some of the groundwater mining and land subsidence issues that had beset the west side since the advent of the deep-well turbine pump in the 1920s, only to have these same problems reemerge at the turn of the century for many of the same reasons-a lack of commitment to sustainable resource planning and a myopic and self-serving refusal to recognize the connectivity between surface and subsurface water resources. In the 1980s, after the tragedy of the selenium poisoning of waterfowl embryos at Kesterson Reservoir awakened the public to the linkage between agricultural return flows and environmental health, the University of California mobilized and engaged in a tsunami of applied research studies that resulted in a greater understanding of agricultural hydrology and of how to control and mitigate water quality impacts that was enshrined in a broad array of mathematical models, at both the field and regional scales, offering potential for decision support. However, these models alone, without the will of the California electorate to make hard policy choices aimed at environmental justice and sustainability, have proved to be ineffectual until relatively recently. As was pointed out in this paper, even a century after Hilgard's pioneering insights [4] and warnings on the topic of sustainable irrigation and salinity, the two primary agency-sponsored surface and groundwater simulation models have no capability to simulate salinity or offer decision support for salt management decision-making. There has, however, been an awakening in recent years of policy makers in the domains of both groundwater and surface water quality resource sustainability.

The RTSM program and SGMA have made up for decades of stakeholder and agency inertia and have shown great promise, to date, in fostering resource management innovation. Since 2014 SGMA planning activities have ushered in the first statutory requirement for measurement and public dissemination of groundwater pumping data and a commitment from stakeholders in self-organized "groundwater sustainability areas" to develop long-term plans to eliminate overdraft and subsidence problems while protecting local aquifers and groundwater quality in groundwater sustainability plans. Technical advances in data acquisition and information dissemination technologies have made possible the implementation of an RTSM program in California's SJRB. RTSM relies on continuously recording sensors that form the backbone of a monitoring network and simulation models that are used to forecast flow and water quality conditions in the receiving waterbody [59] and the tributary watersheds that contribute flow and salt load to the River. Effective implementation of RTSM has an educational and extension requirement, which has yet to be fully realized, as was demonstrated in the SJRRTM Web portal, which, unfortunately, proved too complex and too demanding of stakeholder time to be fully utilized. However, by fusing real-time data reporting and dissemination and model-based salt load assimilative capacity forecasting, stakeholders are beginning to comprehend the connections between SJR drainage salt loading data, SJR riparian diversions, and reservoir release schedules. The two-tiered approach that initially uses a screening tool to identify a potential salinity compliance problem [60], followed by application of the more comprehensive WARMF watershed-based simulation and forecasting model to explore salt management options, should be part of a robust, long-term, and resource-efficient decision support system for SJRB water quality and agriculture sustainability.

Although this paper took a deep dive into irrigation sustainability issues impacting the SJR and SJRB in California, the issues being tackled in California are manifest in arid zones around the world. The State of California, with its abundant resources as one of the world's largest economies, has been able to mobilize considerable research manpower that is focused on these issues of irrigation sustainability. I hope that some of the experience and lessons learned as described in this paper will help guide agriculture in other regions to make appropriate, cost-effective policy decisions moving forward.

Funding: This research received no external funding. 
Acknowledgments: This work was supported by the U.S. Bureau of Reclamation and the State of California through multiple grants and implementation studies. Stakeholder entities including Grassland Water District, Patterson Irrigation District, West Stanislaus Irrigation District, and the California Fish and Wildlife Department have partnered on studies to advance the concept of RTSM.

Conflicts of Interest: The author declares no conflict of interest.

\section{Abbreviations}

\begin{tabular}{|c|c|}
\hline CDWR & California Department of Water Resources \\
\hline CVHM & Central Valley Hydrologic Model \\
\hline CVP & Central Valley Project \\
\hline CVRWQCB & Central Valley Regional Water Quality Control Board \\
\hline CVWB & Central Valley Water Board (same as above) \\
\hline C2VSIM & Central Valley (groundwater/surface water) Simulation Model \\
\hline DMC & Delta-Mendota Canal \\
\hline EC & Electrical conductivity \\
\hline ET & Evapotranspiration \\
\hline EPA & United States Environmental Protection Agency \\
\hline GBP & Grassland Bypass Project \\
\hline GSA & Groundwater Sustainability Area \\
\hline GSP & Groundwater Sustainability Plan \\
\hline HRSTS & Hunter River Salinity Trading Scheme. \\
\hline InSAR & Interferometric Synthetic Aperture Radar \\
\hline ITRC & Irrigation Technology Research Center at California Polytechnic University \\
\hline NOAA & National Oceanic Atmospheric Administration \\
\hline PWD & Panoche Water District \\
\hline ppm & parts per million \\
\hline RTSM & Real-Time Salinity Management \\
\hline RTSMP & Real-Time Salinity Management Plan \\
\hline SGMA & Sustainable Groundwater Management Act \\
\hline SJRIO & San Joaquin River Input-Output Model \\
\hline SJV & San Joaquin Valley \\
\hline SJR & San Joaquin River \\
\hline SJRB & San Joaquin River Basin \\
\hline SJRRTM & San Joaquin River Real-Time Management Web portal \\
\hline SJVDP & San Joaquin Valley Drainage Program \\
\hline SJRIP & San Joaquin River Improvement Project \\
\hline TMDL & Total Maximum Daily Load \\
\hline USBR & United States Bureau of Reclamation \\
\hline USFWS & United States Fish and Wildlife Service \\
\hline USGS & United States Geological Survey \\
\hline VAMP & Vernalis Adaptive Management Plan \\
\hline WARMF & Watershed Analysis Risk Management Framework \\
\hline
\end{tabular}

\section{Appendix A. List of Relevant Metric Conversion Factors}

This paper included referenced material that contains graphics in English units. Rather than attempt to overwrite legends and axes in these materials, metric conversions are provided below for those more familiar with the metric system.

$\begin{array}{lll}1 \text { acre } & = & 0.405 \text { ha } \\ 1 \text { acre-ft } & =1233 \mathrm{~m}^{3} \\ 1 \text { acre-ft } & =0.1233 \text { ha-m } \\ 1 \mathrm{cfs} & =0.0283 \mathrm{~m}^{3} / \mathrm{s} \\ 1 \mathrm{ft} & =0.3048 \mathrm{~m} \\ 1 \mathrm{cu} f t & =0.0283 \\ 1 \text { ton (US) } & =0.907 \text { tonnes } \\ 1 \text { ton (salt)/acre-foot } & =753 \mathrm{mg} / \mathrm{L}\end{array}$




\section{References}

1. Quinn, N.W.T. The San Joaquin Valley: Salinity and Drainage Problems and the Framework for a Response. In Salinity and Drainage in San Joaquin Valley, California; Chang, A.C., Brawer Silva, D., Eds.; Springer Science+Business Media: Dordrecht, The Netherlands, 2014. [CrossRef]

2. State of California, Department of Water Resources. Mavens Notebook. 2009. Available online: https: //mavensnotebook.com/wp-content/uploads/2013/07/Fig3-1.jpg (accessed on 5 June 2020).

3. State of California, Department of Water Resources. Mavens Notebook. 2009. Available online: https: //mavensnotebook.com/wp-content/uploads/2013/04/tributary_map.gif (accessed on 5 June 2020).

4. Hilgard, E. Irrigation and Alkali in India. College of Agriculture, University of California, Report to the President of the University; Bull. No. 86; California State Printing Office: Sacramento, CA, USA, 1889.

5. Galloway, D.; Jones, D.R.; Ingebristen, S.C. Land Subsidence in the United States; Circular 1186; U.S. Geological Survey: Reston, VA, USA, 1999.

6. Faunt, C.C. (Ed.) Groundwater Availability of the Central Valley Aquifer, California: U.S. Geological Survey Professional Paper No. 1766; U.S. Geological Survey: Reston, VA, USA, 2009; p. 225.

7. Sneed, M.; Brandt, J.T.; Solt, M. Land subsidence along the California Aqueduct in west-central San Joaquin Valley, California, 2003-10: U.S. Geological Survey Scientific Investigations Report. 2018-5144; U.S. Geological Survey: Reston, VA, USA, 2018; p. 67. [CrossRef]

8. California Department of Water Resources. Public Update for Drought Response Groundwater Basins with Potential Water Shortages and Gaps in Groundwater Management; California Department of Water Resources: Sacramento, CA, USA, 2014.

9. Moran, T. Projecting forward. A Framework for Groundwater Model Development under the Sustainable Groundwater Management Act; Stanford Law School: Stanford, CA, USA, 2016.

10. State of California, Department of Water Resources. Mavens Notebook. Available online: https: //mavensnotebook.com/2017/04/12/panel-discussion-implementing-sgma-how-are-we-getting-there/ (accessed on 5 May 2020).

11. Hanak, E.; Lund, J.; Arnold, B.; Escriva-Bou, A.; Gray, B.; Green, S.; Harter, T.; Howitt, R.; MacEwan, D.; Medellín-Azuara, J.; et al. Water Stress and a Changing San Joaquin Valley; Public Policy Institute of California: San Francisco, CA, USA, 2017.

12. Stewart, J.A.; Butterfield, H.S.; Richmond, J.Q.; Germano, D.J.; Westphal, M.F.; Tennant, E.N.; Sinervo, B. Habitat restoration opportunities, climatic niche contraction, and conservation biogeography in California's San Joaquin Desert. PLoS ONE 2019, 12, e210766. [CrossRef] [PubMed]

13. Butterfield, H.S.; Cameron, D.; Brand, E.; Webb, M.; Forsburg, E.; Kramer, M.; O’Donoghue, E.; Crane, L. Western San Joaquin Valley Least Conflict Solar Assessment; The Nature Conservancy: San Francisco, CA, USA, Unpublished work; 2003.

14. Almaraz, M.; Bai, E.; Wang, C.; Trousdell, J.; Conley, S.; Faloona, I.; Houlton, B.Z. Agriculture Is a major source of NOx pollution in California. Sci. Adv. 2018, 4, eaao3477. [CrossRef] [PubMed]

15. Dogrul, E.C.; Schmid, W.; Hanson, R.T.; Kadir, T.; Chung, F. Integrated Water Flow Model and Modflow-Farm Process: A Comparison of Theory, Approaches, and Features of Two Integrated Hydrologic Models; Technical Information Record; California Department of Water Resources: Sacramento, CA, USA, 2011.

16. Schmid, W.; Dogrul, E.C.; Hanson, R.T.; Kadir, T.; Chung, F. Comparison of Simulations of Land-use Specific Water Demand and Irrigation Water Supply by MF-FMP and IWFM; Technical Information Record; California Department of Water Resources: Sacramento, CA, USA, 2011.

17. Brush, C.F.; Dogrul, E.C.; Kadir, T.N. Development and Calibration of the California Central Valley Groundwater-Surface Water Simulation Model (C2VSim); Version 3.02-CG; Bay-Delta Office, California Department of Water Resources: Sacramento, CA, USA, 2013.

18. Maples, S.; Fogg, G.E.; Foglia, L.; Harter, T. Evaluating Groundwater Budget Estimates in an Agriculturally-Intensive Alluvial Aquifer System-Effects of Scale, Complexity, and Data Availability. In Proceedings of the AGU Fall Meeting, San Francisco, CA, USA, 9-13 December 2019.

19. Maples, S. Simulating Recharge Processes and Evaluating Groundwater Budget Estimates in California's Central Valley Aquifer System. Ph.D. Thesis, University of California, Davis, CA, USA, 2019.

20. Bastiaanssen, W.G.M.; Menenti, M.; Feddes, R.A.; Holtslag, A.A.M. A remote 660 sensing surface energy balance algorithm for land (SEBAL). 1. Formulation. J. Hydrol. 1998, 212, 198-212. [CrossRef] 
21. Allen, R.G.; Morton, C.; Kamble, B.; Kilic, A.; Huntington, J.; Thau, D.; Gorelick, S.; Erickson, T.; Moore, R.; Trezza, R.; et al. EEFlux: A Landsat-Based Evapotranspiration Mapping Tool on the Google Earth Engine. Emerging Technologies for Sustainable; Conference Proceedings; American Society of Agricultural and Biological Engineers: St Joseph, MI, USA, 2015.

22. Hoffman, G.J. Drainage Required to Manage Salinity. J. Irrig. Drain. Eng. 1985, 111, 199-206. [CrossRef]

23. Hoffman, G.J. Salt Tolerance of Crops in the Southern Sacramento-San Joaquin Delta; Prepared on Behalf of the California Environmental Protection Agency, State Water Resources Control Board, Division of Water Rights; Final Report; California Environmental Protection Agency: Sacramento, CA, USA, 2010.

24. Hoffman, G.J.; Van Genuchten, M.T. Water management for salinity control. In Limitations to Efficient Water Use in Crop Production; Taylor, H., Jordan, W., Sinclair, T., Eds.; American Society of Agronomy: Madison, WI, USA, 1983; pp. 73-85.

25. Hoffman, G.J.; Rhoades, J.D.; Letey, J.; Sheng, F. Salinity management. In Management of Farm Irrigation Systems; Hoffman, G.J., Howell, T.A., Solomon, K.H., Eds.; American Society of Agricultural Engineers: St. Joseph, MI, USA, 1990; pp. 667-715.

26. San Joaquin Valley Drainage Program. A Management Plan for Agricultural Subsurface Drainage and Related Problems on the Westside San Joaquin Valley; Final Report, September 1990; San Joaquin Valley Drainage Program: Sacramento, CA. USA, 1990.

27. Grismer, M.E.; Gates, T.K. Hydrologic Aspects of Saline Water Table Management in Regional Shallow Aquifers. In The Economics and Management of Water and Drainage in Agriculture; Dinar, A., Zilberman, D., Eds.; Springer: Boston, MA, USA, 1991; ISBN 978-1-4615-4028-1.

28. National Research Council. Irrigation-Induced Water Quality Problems. What Can Be Learned from the San Joaquin Valley Experience? National Academy Press: Washington, DC, USA, 1989.

29. Orlob, G.T. San Joaquin salt balance: Future prospects and possible solutions. In The Economics and Management of Water and Drainage in Agriculture; Dinar, A., Zilberman, D., Eds.; Kluwer Publishing Co.: Alphen aan den Rijn, The Netherlands, 1991; pp. 143-167.

30. Kratzer, C.; Grober, L. San Joaquin River salinity: 1991 Projections Compared to 1977. Calif. Agric. 1991, 45, 24-27. [CrossRef]

31. Kratzer, C.R.; Pickett, P.J.; Rashmawi, E.A.; Cross, C.L.; Bergeron, K.D. An Input Output Model of the San Joaquin River from the Lander Avenue Bridge to the Airport Way Bridge; Appendix C of the California State Water Resources Control Board; Technical Committee Report on Regulation of Agricultural Drainage to the San Joaquin River; California State Water Resources Control Board: Sacramento, CA, USA, 1987; 173p.

32. Burt, C.M. On Farm Irrigation Management-The Shift from Art to Science. In Proceedings of the Irrigation Association of Australia 1998 Conference, Brisbane, Australia, 19-21 May 1998.

33. Burt, C.M.; Clemmens, A.J.; Strelkoff, T.S.; Solomon, K.H.; Bliesner, R.D.; Hardy, L.A.; Howell, T.A.; Eisenhauer, D.E. Irrigation Performance Measures_Efficiency and Uniformity. J. Irrig. Drain. Eng. 1997, 123, 423-442. [CrossRef]

34. Hatchett, S.A.; Quinn, N.W.T.; Horner, G.L.; Howitt, R.E. Drainage Economics Model to Evaluate Policy Options for Managing Selenium Contaminated Drainage. Toxic Substances in Agricultural water Supply and Drainage-An International Perspective. In Proceedings of the International Committee on Irrigation and Drainage, Ottawa, ON, Canada, 8-9 June 1989.

35. Quinn, N.W.T. Overview of the Use of the Westside Agricultural Drainage Economics Model (WADE) for Plan Evaluation; Technical Information Record; San Joaquin Valley Drainage Program: Sacramento, CA, USA, 1990.

36. Belitz, K.R.; Heimes, F.J. Character and Evolution of the Ground-Water Flow System in the Central Part of the Western San Joaquin Valley, California; Water Supply Paper; No.2348; US Geological Survey: Reston, VA, USA, 1990; p. 28.

37. Letey, J.; Knapp, K. Crop-Water Production Functions under Saline Conditions. In Agricultural Salinity Assessment and Management; ASCE Manuals and Reports on Engineering Practice; No. 71; Tanji, K.K., Ed.; American Society of Civil Engineers: Reston, VA, USA, 1990; pp. 305-326.

38. Burt, C.M.; Walker, R.E.; Canessa, P.; Robison, K. Irrigation and Drainage in the Grassland Area of the Westside of the San Joaquin Valley; California Polytechnic State University: San Luis Obispo, CA, USA, 1992. 
39. Ayars, J.E.; Hoffman, G.J.; Phene, C.J. Irrigation Systems and Management Alternatives for Reducing Drainage from Irrigated Agriculture. In Proceedings of the Regional Meeting-United States Committee on Irrigation and Drainage (USCID), Sacramento, CA, USA, 15-17 November 1987; pp. 61-69.

40. Kruse, E.G.; Willardson, L.; Ayars, J. On-farm irrigation and drainage practices. In Agricultural Salinity Assessment and Management; Manuals and Reports of Engineering Practice; No. 71; Tanji, K.K., Ed.; American Society of Civil Engineers: Reston, VA, USA, 1990; pp. 349-371.

41. Knapp, K.C.; Wichelns, D. Dynamic optimization models for salinity and drainage management. In Agricultural Salinity Assessment and Management; Manuals and Reports of Engineering Practice; No. 71; Tanji, K.K., Ed.; American Society of Civil Engineers: Reston, VA, USA, 1990; pp. 530-548.

42. Knapp, K.C. Irrigation management and investment under saline limited drainage conditions, 1 . Model formulation. Water Resour. Res. 1992, 28, 3085-3090. [CrossRef]

43. Knapp, K.C. Irrigation management and investment under saline limited drainage conditions, 2. Characterization of optimal decision rules. Water Resour. Res. 1992, 28, 3091-3097. [CrossRef]

44. Knapp, K.C. Irrigation management and investment under saline limited drainage conditions, 3. Policy analysis and extensions. Water Resour. Res. 1992, 28, 3099-3109. [CrossRef]

45. Dinar, A.; Aillery, M.D.; Moore, M.R. A dynamic model of soil salinity and drainage generation in irrigated agriculture: A framework for analysis. Water Resour. Res. 1993, 29, 1527-1537. [CrossRef]

46. Dinar, A.; Zilberman, D. (Eds.) The Economics and Management of Water and Drainage in Agriculture; Springer: Boston, MA, USA, 1991; ISBN 978-1-4615-4028-1.

47. Carlson, G.A.; Zilberman, D.; Miranowski, J.A. (Eds.) Agricultural and Environmental Resource Economics; Oxford University Press: New York, NY, USA, 1993.

48. Casey, F.; Schmitz, A.; Swinton, S.; Zilberman, D. Flexible Incentives for the Adoption of Environmental Technologies in Agriculture; Kluwer Academic Publishers: Norwell, MA, USA, 1999.

49. Quinn, N.W.T.; Brekke, L.D.; Miller, N.; Heinzer, T.; Hidalgo, H.; Dracup, J.A. Model Integration For Assessing Future Hydroclimate Impacts on Water Resources, Agricultural Production and Environmental Quality in the SJRB, California. Environ. Model. Softw. 2004, 19, 305-316. [CrossRef]

50. California Environmental Protection Agency. Total Maximum Daily Load for Salinity and Boron in the Lower San Joaquin River; Staff report by the California Regional Water Quality Control Board, Central Valley Region; California Environmental Protection Agency: Sacramento, CA, USA, 2002.

51. Herr, J. Watershed Analysis Risk Management Framework (WARMF); User Guide and Documentation of the Graphical User Interface; Systech Water Resources Inc.: San Ramon, CA, USA, 2017.

52. California Environmental Protection Agency. Total Maximum Daily Load for Salinity and Boron in the Lower San Joaquin River; Staff report by the Regional Water Quality Control Board, Central Valley Region; California Environmental Protection Agency: Sacramento, CA, USA, 2004.

53. Central Valley Regional Water Quality Control Board (CVWB). Amendments to the Water Quality Control Plan for the Sacramento River and San Joaquin River Basin; Draft Final Staff Report and Technical TMDL Report; Central Valley Regional Water Quality Control Board: Sacramento, CA, USA, 2018.

54. Brownell, J. Schedule of Potential Annual Penalties. Unpublished work. 2013.

55. Quinn, N.W.T.; Karkoski, J. Real-Time Management of Water Quality in the San Joaquin River Basin, California; American Water Resources Association: Middleburg, VA, USA, 1998; Volume 34.

56. Quinn, N.W.T.; Hanna, W.M. A decision support system for adaptive real-time management of seasonal wetlands in California. Environ. Model. Softw. 2003, 18, 503-511. [CrossRef]

57. Chen, C.W.; Herr, J.; Weintraub, L.H.Z. Watershed Analysis Risk Management Framework: Update One: A Decision Support System for Watershed Analysis and Total Maximum Daily Load Calculation, Allocation, and Implementation; EPRI: Palo Alto, CA, USA, 2001.

58. Herr, J.; Chen, C.W.; Van Werkhoven, K. Final Report for Task 6 Modeling of the San Joaquin River. CALFED Project ERP-02D-P63. Monitoring and Investigations for the San Joaquin River and Tributaries Related to Dissolved Oxygen; Systech Water Resources Inc.: Walnut Creek, CA, USA, 2008.

59. Quinn, N.W.T.; Hughes, B.; Osti, A.; Herr, J.; Wang, J. Real-time, web-based decision support for stakeholder implementation of basin-scale salinity management. In Environmental Software Systems, Computer Science for Environmental Protection, Proceedings of the International Symposium on Environmental Software Systems, Zadar, Croatia, 10-12 May 2017; IFIP AICT 507; Hrebicek, J., Denzer, R., Schimak, G., Pitner, T., Eds.; Springer: Berlin/Heidelberg, Germany, 2018. 
60. Lu, J.; Wang, J.; Raley, E.; Quinn, N.W.T.; Kabir, J. An Alternative Approach to Salinity Forecasting in the Lower San Joaquin River. In Modern Environmental Science and Engineering; Academic Star Publishlishing Company: New York, NY, USA, 2019; ISSN 2333-2581.

61. Quinn, N.W.T. Contrasts in the use of information technology for real-time salinity management in the San Joaquin Basin, California, USA and Hunter River Basin, New South Wales, Australia. Agric. Water Manag. 2011, 98, 930-940. [CrossRef]

62. Hunter River Salinity Trading Scheme (HRSTS) in New South Wales, Australia. Available online: https: //apps.epa.nsw.gov.au/HRSTSPublicApp/Default.aspx (accessed on 25 May 2020).

63. U.S. Bureau of Reclamation. San Luis Drainage Feature Re-Evaluation; Record of Decision and Final Environmental Impact Statement; U.S. Bureau of Reclamation: Washington, DC, USA, 2007.

64. U.S. Bureau of Reclamation. Grassland Bypass Project, 2010-2019. Record of Decision and Final Environmental Impact Statement/Environmental Impact Report; Entrix for Mid-Pacific Region, South-Central California Area Office: Fresno, CA, USA, 2009.

65. U.S. Bureau of Reclamation. Grassland Bypass Project 2008 Annual Report; Mid-Pacific Region, South-Central California Area Office: Fresno, CA, USA, 2009.

66. Caswell, M.F.; Zilberman, D. "The effects of well depth and land quality on the choice of irrigation technology". Am. J. Agric. Econ. 1986, 68, 798-811. [CrossRef]

67. Zilberman, D.; Khanna, M.; Lipper, L. Economics of New Technologies for Sustainable Agriculture. Aust. J. Agric. Resour. Econ. 1997, 41, 63-80. [CrossRef]

68. Singh, A.; Quinn, N.W.T.; Benes, S.E.; Cassel, F. Policy-driven sustainable saline drainage disposal and forage production in the western San Joaquin Valley of California. Sustainability 2020, submitted.

(C) 2020 by the author. Licensee MDPI, Basel, Switzerland. This article is an open access article distributed under the terms and conditions of the Creative Commons Attribution (CC BY) license (http://creativecommons.org/licenses/by/4.0/). 